\title{
TECENDO A PRECARIZAÇÃO: \\ TRABALHO A DOMICÍLIO E ESTRATÉGIAS SINDICAIS NA INDÚSTRIA DE CONFECÇÃO EM SÃO PAULO
}

\author{
WEAVING PRECARIOUSNESS: \\ HOME-BASED WORKERS AND THE TRADE UNIONS' STRATEGIES \\ IN SÃO PAULO'S CLOTHING INDUSTRY
}

Marcia de Paula Leite 1

Resumo O artigo, à luz da indústria de confecções de São Paulo, discute as transformações das relações e das condições de trabalho no contexto da reestruturação produtiva. Para tal, o texto trata, de forma pormenorizada, da divisão do trabalho entre as empresas no interior da cadeia produtiva e das relações de trabalho que predominam nos diferentes níveis da mesma, com especial ênfase no trabalho a domicílio. A análise revela que, à medida que o processo de terceirização avança, o emprego diminui na ponta virtuosa da cadeia - as empresas líderes dos encadeamentos produtivos - onde se difunde o trabalho qualificado, mais bem pago e mais estável, e aumenta na ponta precária, onde abunda o trabalho pouco qualificado, instável, mal pago e, muitas vezes, executado sem vínculo empregatício - ou seja, onde se difundem as condições de trabalho e relações de emprego mais deterioradas. $\mathrm{O}$ artigo discute ainda como essas antigas formas de trabalho revitalizadas em um novo contexto atingem mais fortemente as mulheres do que os homens, evidenciando a exclusão social dos setores mais vulneráveis do mercado de trabalho2.

Palavras-chave trabalho a domicílio; gênero e trabalho; precarização do trabalho.
Abstract Using as reference São Paulo's clothing industry and in the context of the restructuring of production processes, this article discusses the recent changes in labour relations and labour conditions. For this purpose, the text looks closely at the division of labour among the companies within the productive chain and at the labour relations prevailing in its various levels, with special emphasis on home-based workers. The analysis reveals that, as the out-contracting process advances, the number of jobs decreases in the virtuous end of the productive chain - that is, in the leading companies, where labour is better qualified, earns higher salaries and has more stability; and increases in its precarious end - that is, where work conditions and labour relations are worse, and where there is a majority of unskilled, low-paid and less stable jobs, often without a proper work contract. The article also discusses how these work conditions, brought back to life in a new context, affect female workers much more than male ones, clearly showing the social exclusion of the more vulnerable sectors of the labour market.

Key words home-based workers; gender and work; precariousness of jobs. 


\section{Introdução}

Já não são poucos os estudos internacionais que destacam as profundas implicações das transformações que vêm ocorrendo na estrutura industrial sobre o trabalho. Acompanhando a globalização econômica e as novas tendências de organização da produção, tais transformações têm constituído cadeias produtivas que se conformam em vários níveis de fornecimento, ao contrário das estruturas formadas pelas grandes empresas e seu enorme conjunto de fornecedores, predominantes durante o fordismo 3 .

Atendendo às necessidades de flexibilização da produção e adequandose à lógica do atual estágio de desenvolvimento econômico — baseado mais na dinâmica do capital financeiro que do produtivo - , esses novos arranjos se caracterizam pela tendência ao enxugamento das empresas por meio da externalização de partes do processo produtivo para terceiros. Esse movimento em cascata acaba por configurar a cadeia de produção em um conjunto de diferentes níveis de provimento.

A identificação desses novos arranjos, originalmente na indústria automobilística japonesa e, a seguir, em vários outros setores produtivos dos países industrializados, ensejou uma grande controvérsia a respeito de suas conseqüências sobre o trabalho. Um conjunto de estudos sublinhou seus efeitos virtuosos, tendo em vista a difusão, para o conjunto da cadeia, dos novos conceitos de produção introduzidos nas empresas líderes desses encadeamentos (Piore e Sabel, 1984; Coriat, 1992; Womack et al., 1992). Porém, muitas outras pesquisas acentuaram a desigualdade das condições de trabalho ao longo das cadeias (Kamada, 1994), destacando seu caráter, ao mesmo tempo, contraditório e complementar (Castillo e Santos, 1993; Benería e Roldán, 1987).

Conforme o processo de globalização se aprofundava, esses novos achados começaram a ser complementados pelos estudos sobre mercado de trabalho que trouxeram à tona um profundo processo de deterioração das condições de emprego. O cotejamento entre essas duas tendências permitiu identificar que, à medida que as grandes empresas terceirizam partes de seu processo produtivo, o trabalho é também transferido a empresas em geral menores, que se dedicam a parcelas mais simples do processo de produção, nas quais as condições de trabalho e relações de emprego tendem a ser mais precárias 4 . Novos estudos sobre mercado de trabalho vêm confirmando as suspeitas de que, à medida que o processo avança, o trabalho diminui na ponta virtuosa da cadeia (as empresas líderes dos encadeamentos produtivos, onde se difunde o trabalho qualificado, mais bem pago e mais estável) e aumenta na ponta precária, onde abunda o trabalho pouco qualificado, instável, mal pago e, muitas vezes, executado sem vínculo empregatício. Esses estudos evidenciam cada vez mais o crescente aumento do trabalho sem 
registro, revertendo a tendência observada até o fim dos anos 70, de aumento do trabalho registrado, exercido nas grandes empresas.

É neste contexto que se multiplicam novas e velhas formas de trabalho que, ao invés de marginais ao desenvolvimento econômico, se mostram altamente funcionais, como o trabalho temporário, em domicílio, part time etc. E, o que é mais grave ainda, os estudos voltados à segmentação de gênero no mercado de trabalho indicam que essas novas formas de trabalho que incluem velhas formas reativadas no novo contexto - atingem mais fortemente as mulheres do que os homens, configurando uma situação que, longe dos auspiciosos resultados dos primeiros estudos, descortina uma realidade marcada pela exclusão social dos setores mais vulneráveis do mercado de trabalho.

Essas características atingem, sobretudo, alguns setores que sempre empregaram essas formas de trabalho, como a indústria da confecção, internacionalmente apontada como um setor onde se difundem novas práticas de trabalho a domicílio ${ }^{5}$. Por outro lado, essa realidade apresenta aos sindicatos do mundo inteiro um conjunto enorme de novos desafios que eles buscam enfrentar de formas muito variadas, algumas mais, outras menos adequadas à gravidade da situação.

É a este debate que o presente texto remete, a partir de um estudo realizado na indústria de confecção em São Paulo. Nele, exploramos as tendências do trabalho na cadeia do vestuário, com especial ênfase na discussão sobre o trabalho a domicílio. Buscamos explorar também a maneira como o sindicalismo brasileiro vem respondendo às novas tendências que o trabalho vem assumindo. As questões que tentaremos discutir de forma mais pormenorizada se referem à divisão do trabalho entre as empresas no interior da cadeia, às relações de trabalho que predominam nos diferentes níveis do encadeamento produtivo, às características que assume o trabalho a domicílio nesse novo contexto, aos desafios que essas mudanças vêm apresentando para o movimento sindical e à forma como esse movimento vem respondendo à nova realidade. Para tanto, o texto será organizado em dez sessões: 1) a pesquisa; 2) o setor de confecções no Brasil; 3) a dimensão de gênero; 4) a "cara" da terceirização; 5) a cadeia; 6) as confeccionistas; 7) as oficinas de costura; 8) o trabalho a domicílio; 9) estratégias sindicais na cadeia do vestuário; e 10) conclusão.

\section{A pesquisa}

A pesquisa se desenvolveu por meio de levantamentos de dados sobre o setor de confecções no Brasil e de estudos de caso realizados em empresas do setor em São Paulo. Para discutir as práticas sindicais voltadas ao enfrenta- 
mento da deterioração das condições de trabalho e à proteção do trabalho a domicílio, fizemos também um levantamento de experiências sindicais na indústria do vestuário.

Quanto aos estudos de caso, foram visitadas três empresas de confecção, seis oficinas de costura e quatro trabalhadoras a domicílio. No primeiro caso, foram realizadas entrevistas semi-abertas, nas próprias empresas, com seus gerentes; nas oficinas de costura, foram conduzidas entrevistas abertas com seus donos; finalmente, foram entrevistadas as trabalhadoras a domicílio, a partir de um roteiro, em suas próprias casas.

Já a pesquisa com os sindicatos foi feita por meio de entrevistas com suas lideranças, realizadas no sindicato (Confederação Nacional dos Trabalhadores na Indústria do Vestuário e Sindicato das Costureiras de São Paulo e Osasco) ou de telefonemas (Sindicato dos Trabalhadores nas Indústrias de Confecções e Bordados de Ibitinga e Região), complementados com documentos oficiais fornecidos pelo sindicato.

No que respeita aos estudos de caso, buscamos selecionar empresas em diferentes pontos da cadeia produtiva, a fim de compreender a organização industrial e a organização da produção em seu conjunto. É importante assinalar que a amostra não pretende representatividade estatística, já que optamos por trabalhar com segmentos de cadeias que expressassem diferentes arranjos institucionais, buscando evidenciar a heterogeneidade da estrutura industrial do setor. Este tipo de escolha metodológica e o tamanho relativamente reduzido da amostra restringem, evidentemente, as possibilidades de conclusões quantitativas, uma vez que foram privilegiados os aspectos qualitativos da realidade.

Foram investigados três segmentos de cadeias, com características bastante distintas, assim constituídas:

- Cadeia A: Esta é liderada por uma empresa nacional produtora de cosméticos (empresa líder 1). A análise deste segmento compreendeu o estudo de uma empresa produtora de bolsas acondicionadoras de cosméticos (confecção 1), uma oficina de costura (oficina 1) e quatro trabalhadoras a domicílio.

- Cadeia B: Este segmento é comandado por uma grande empresa nacional (empresa líder 2), detentora de uma marca famosa de roupa jovem que foi uma grande empresa de confecção, mas que vem, cada vez mais, direcionando seus esforços para a distribuição, relegando a produção a um segundo plano. A empresa mantém, entretanto, uma parte ainda importante da modelagem e corte, motivo pelo qual será classificada aqui como confeccionista (confecção 2). A pesquisa envolveu também duas oficinas de costura (oficinas 2 e 3 ).

- Cadeia C: A pesquisa deste segmento foi desenvolvida por meio do estudo de uma grande distribuidora de roupas (empresa líder 3), uma em- 
presa de confecções (confecção 3) e duas oficinas de costura (oficinas 4 e 5).

Faz parte ainda do estudo uma sexta oficina de costura que nos foi indicada, enganosamente, como pertencente à cadeia 2. Embora não esteja inserida em nenhuma das cadeias estudadas, ela fará parte da análise das oficinas (oficina 6), tendo em vista que representa um caso típico de oficina que trabalha para pequenos distribuidores, dedicados apenas à intermediação entre as confecções e as oficinas de costura.

Vale ressaltar que, embora o trabalho a domicílio apareça no último nível da cadeia, na utilização de costureiras que trabalham para as oficinas, muitas destas últimas já se configuram, elas próprias, como formas de trabalho a domicílio, tendo em vista sua organização familiar (como no caso da oficina 5), uma vez que muitas delas nada mais são do que formas de evolução do trabalho a domicílió.

O gráfico 1 apresenta, de forma esquemática, a relação entre as empresas que compõem os segmentos de cadeia pesquisados. Como se pode ver, nem sempre estão presentes os diferentes níveis da cadeia, havendo empresas de distribuição que são, ao mesmo tempo, confeccionistas, como no caso da empresa líder 2.

\section{Gráfico 1}

Relação entre as empresas componentes dos segmentos pesquisados
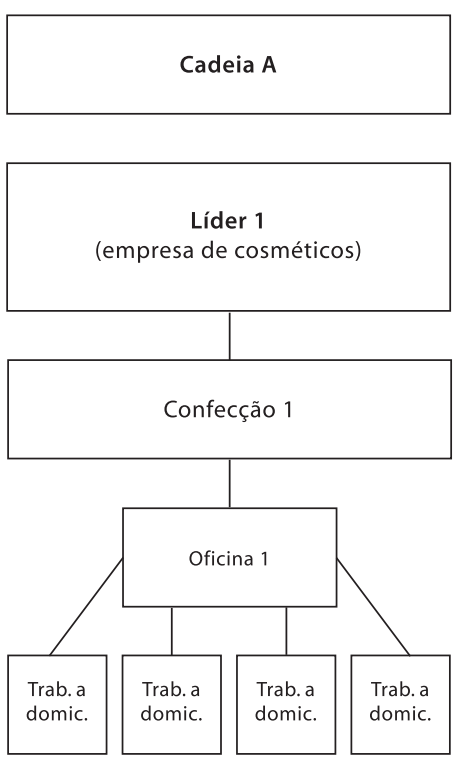
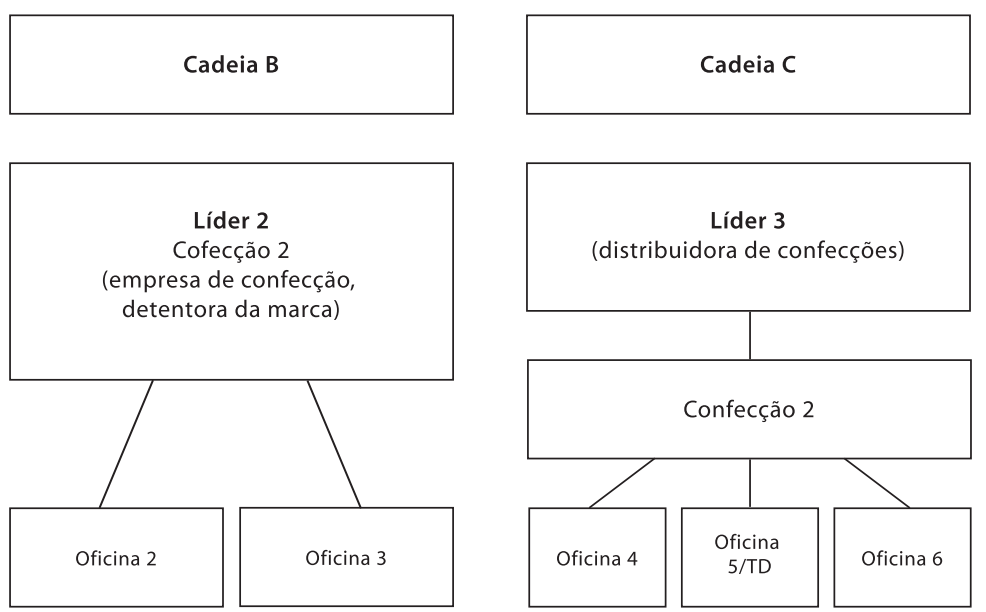


\section{O setor de confecções no Brasil}

As dimensões atuais da indústria de confecção no Brasil situam o país no quarto posto entre os principais produtores mundiais. Acompanhando o processo de industrialização e urbanização do país, a explosão do mercado de roupas confeccionadas industrialmente se dinamizou a partir da década de 60. Atualmente, o setor de confecções é formado por um numeroso grupo de pequenas e médias empresas, dedicadas à produção de artigos do vestuário e decorativos e de produtos técnicos. De acordo com dados do Instituto de Estudos e Marketing Industrial (Iemi), as confecções de grande porte representam pouco mais de $2,5 \%$ do total das indústrias e dominam pouco menos de $40 \%$ do mercado. A maior parcela da produção provém das médias empresas, que respondem por $50 \%$ dos volumes produzidos (site do Iemi).

O setor têxtil e de confecções vivia, em seu conjunto, uma situação bastante difícil no início da década de 90, marcada pela baixa capacitação tecnológica. O cenário se mostrava ainda pior na área da confecção, onde, de acordo com Coutinho e Ferraz (1994, p. 312), prevalecia a produção com deficiências competitivas, sendo pouco significativa a participação das empresas líderes no mercado internacional.

Os autores chamavam a atenção para o pequeno porte das empresas do setor e as dificuldades daí oriundas para o investimento e a adoção de estratégias competitivas e de busca de mercados mais dinâmicos do que o brasileiro. Nesse contexto, a indústria do vestuário apresentava sérias limitações quanto à qualidade e à produtividade, encontrando-se à mercê da estagnação do mercado interno brasileiro, o que se refletia em sua inexpressiva capacidade de exportação, correspondente a menos de $2 \%$ da produção em 1990 (Coutinho e Ferraz, 1994, p. 316). Conforme advertiam eles:

\footnotetext{
“o acirramento da concorrência neste mercado e a virtual ausência de redes horizontais ou verticais que confiram a pequenas empresas melhores condições para superar conjunturas desfavoráveis têm impedido a difusão de práticas competitivas das empresas de maior capacitação para as demais e exigido o recurso crescente a estratégias não-competitivas de sobrevivência. Têm aumentado nesses setores a informalização, a sonegação fiscal e a degradação das condições de trabalho" (Coutinho e Ferraz, 1994, p. 312).
}

A falta de capacitação gerencial e tecnológica das pequenas empresas emergia, portanto, como um dos principais entraves ao desenvolvimento tecnológico do setor em seu conjunto e, o que era pior, a situação tendia ao agravamento: 
“esse problema tem se agravado com a intensificação do recurso à subcontratação de empresas menores nos últimos anos. As relações entre as partes geralmente são conflitivas, já que não são motivadas por formas evoluídas de gestão, onde ganhos de produtividade derivados da especialização formam a base da relação contratual. No Brasil, a integração produtiva tem visado apenas a redução de custos diretos, sem grandes preocupações com qualidade. Freqüentemente, é motivada pelas possibilidades de contornar obrigações tributárias e encargos sociais" (Coutinho e Ferraz, op. cit., p. 324).

Nesse quadro, os autores destacam que, além da concorrência desleal para com empresas organizadas, "este processo tem elevados custos sociais, ao manter uma parcela crescente da mão-de-obra sem cobertura da legislação trabalhista e previdenciária. A produção 'isenta' de tributos e encargos sociais torna não-competitivas em preços empresas que cumprem as obrigações legais, tornando quase inevitável a participação destas no processo de informalização" (Coutinho e Ferraz, op. cit., p. 339).

As empresas viviam profundas dificuldades naquele momento, provocadas, sobretudo, pela crise econômica desencadeada, em 1990, com o Plano Collor e a abertura comercial que a ele se seguiu. Segundo Araújo e Amorim (2000, p. 5), a diminuição da produção foi bastante significativa nesses anos: “o número de falências no estado de São Paulo no período 1993-1995 no setor de vestuário, calçados e artefatos de tecidos aumentou $86,88 \%$ e a contribuição do segmento de vestuário para o aumento do desemprego entre 1993-1996 correspondeu a 40,69\%".

A resposta à crise foi a busca da competitividade de forma bastante heterogênea, por meio de medidas voltadas à reestruturação do setor. No entanto, a manutenção das condições econômicas do país - ausência de políticas industriais setoriais mais efetivas ${ }^{7}$, continuação da estagnação do mercado interno e dificuldades de crédito industrial, sobretudo para as pequenas e médias empresas - fez com que o quadro encontrado no início da década permanecesse relativamente inalterado para o setor de confecção ${ }^{8}$.

A inovação tecnológica tem-se restringido, assim, às fases anteriores à costura: design, modelagem, encaixe (em que vêm sendo utilizados sistemas $\mathrm{CAD}^{9}$ ) e corte (em que vêm sendo adotados equipamentos de controle numérico). Na etapa principal do ciclo produtivo - a costura, que representa $80 \%$ do trabalho vivo - , a superação da defasagem tecnológica não tem sido observada, o que "faz com que a indústria de confecção ainda se estruture no binômio máquina de costura/costureira" (Araújo e Amorim, 2000, p. 6).

Nesse contexto, a reestruturação tem-se concentrado nas transformações relacionadas à estrutura industrial, onde o padrão de mudança tem adquirido as seguintes características: “concentração no topo, eliminação rá- 
pida de parte substancial das médias empresas e proliferação das unidades de menor porte, formais e informais, sobretudo essas" (Comin, 2000, p. 11). O profundo processo de terceirização que marca a reestruturação do setor não pode ser entendido, contudo, sem que se considere a tradicional tendência ao uso da externalização da produção. De fato, o novo para o setor não é o recurso à externalização - utilizado desde sempre por meio da contratação de costureiras a domicílio em momentos de pico da produção mas, como bem observam Araújo e Amorim (2000, p. 9), “a constituição de 'unidades produtivas externas' mais lucrativas", as oficinas, as quais baseiam esse desempenho seja na ausência de encargos sociais, seja no nível de produtividade alcançado devido à forma de pagamento adotada (por peça). Nesse sentido, a terceirização vem ganhando um papel absolutamente central no processo de reestruturação do setor, conforme têm apontado diversas pesquisas recentes (Lima, 1998, 1999 e 2002; Comin, 2000; Moreira, 1997; Amorim e Araújo, 2002; Amorim, 2003). Como adverte esta última autora:

“a terceirização foi aprofundada não só por ter se difundido entre empresas de diferentes tamanhos, mas por ter suas distintas modalidades de subcontratação resgatadas e generalizadas como sendo a melhor alternativa para se obter lucratividade em escala ampliada. Entre estas modalidades destacam-se a revitalização do trabalho domiciliar e a implantação de cooperativas. Como os salários pagos pelo setor de confecção já são baixos, os empregadores procuraram reduzir os custos com os encargos sociais e com os gastos da produção, transferindo-os para as trabalhadoras domiciliares ou para as trabalhadoras em cooperativas" (Amorim, 2003, p. 88 , grifos nossos).

Vale observar, entretanto, que, apesar desses problemas, a indústria de confecção continua a ocupar um papel importante no conjunto da produção industrial brasileira: o setor é constituído de quase 17.400 unidades fabris, gerando cerca de 1,2 milhão de empregos diretos e movimentando mais de US\$ 22 bilhões (de produção), com uma participação superior a 4\% do PIB. Dentre os seus principais segmentos, destaca-se o do vestuário, que responde pelo maior e mais representativo negócio da indústria de confecções.

Observe-se também que, a partir de 1998, o setor inicia um processo importante de recuperação, devido à desvalorização da moeda nacional e à redução das importações. Nesse contexto, ele vem apresentando um desempenho bastante favorável no que se refere ao balanço de pagamentos nos últimos anos, conforme mostrado nas tabelas 1 e 2.

Os números da produção em peças revelam que a recuperação se torna evidente, pois aumentaram de 4,4 bilhões em 1990 para 9,6 bilhões de peças em 2000, de acordo com dados do Iemi em 2001 (Amorim, 2003, p. 66). 
Tabela 1

\begin{tabular}{lcccccc}
\hline Importações brasileiras de produtos têxteis por linhas de produtos $-1998-2000$ \\
\hline Linhas de produtos & \multicolumn{2}{c}{ jan-dez 1998} & \multicolumn{2}{c}{ jan-dez 1999 } & \multicolumn{2}{c}{ jan-set 2000 } \\
& toneladas & US\$ mil & toneladas & US\$ mil & toneladas & US\$ mil \\
\hline Confeccionados & 40.788 & 353.445 & 25.820 & 188.673 & 21.549 & 124.335 \\
Roupas malha & 10.853 & 100.178 & 5.141 & 52.306 & 3.711 & 37.684 \\
Roupas tecido plano & 10.585 & 202.040 & 8.542 & 107.871 & 8.037 & 65.288 \\
Linha lar & 3.280 & 24.961 & 1.368 & 11.592 & 832 & 7.235 \\
Outras confecções & 16.070 & 26.266 & 10.769 & 16.904 & 8.969 & 14.128 \\
\hline
\end{tabular}

Fonte: Iemi.

Tabela 2

\begin{tabular}{lrrrrrr}
\hline \multicolumn{7}{l}{ Exportações brasileiras de produtos têxteis por linhas de produtos - 1998-2000 } \\
\hline Linhas de produtos & \multicolumn{2}{c}{ jan-dez 1998 } & \multicolumn{2}{c}{ jan-dez 1999 } & \multicolumn{2}{c}{ jan-set 2000 } \\
& toneladas & US\$ mil & toneladas & US\$ mil & toneladas & US\$ mil \\
\hline Confeccionados & 37.076 & 411.141 & 41.319 & 398.153 & 43.771 & 400.024 \\
Roupas malha & 5.350 & 96.388 & 7.786 & 107.668 & 10.974 & 136.203 \\
Roupas tecido plano & 4.844 & 81.811 & 3.679 & 59.155 & 4.385 & 66.049 \\
Linha lar & 22.227 & 202.501 & 24.624 & 205.671 & 23.386 & 173.335 \\
Outras confecções & 5.655 & 30.441 & 5.200 & 25.646 & 5.026 & 24.437 \\
\hline
\end{tabular}

Fonte: Iemi.

Não se pode ignorar, contudo, que o padrão de inserção internacional do país continua baseado fundamentalmente em produtos de menor valor agregado, sem marcas e que disputam espaços na base de preços (Comin, 2000, p. 28).

Finalmente, um último ponto a considerar nesse processo de reestruturação do setor se refere à reespacialização da indústria no país. O setor vem sofrendo um processo significativo de transferência da produção da Região Sudeste (notadamente os estados de São Paulo e Rio de Janeiro) para as demais regiões do país, em especial a Região Sul (na qual se destacam os estados do Paraná e Santa Catarina). Como se pode notar na tabela 3, enquanto o emprego diminuiu de forma expressiva sua participação na Região Sudeste de 1986 a 1997 (de 71,6\% para 58,2\%), ele cresceu em todas as demais regiões do país no mesmo período.

Embora esses dados possam indicar uma tendência positiva de descentralização da produção, se considerarmos as diferenças salariais entre os estados dessas regiões e os incentivos fiscais que esses estados vêm oferecendo para atrair novos investimentos, fica claro o sentido dessa reespacialização: a competição por preços. 
Distribuição do emprego nas indústrias do vestuário segundo as regiões geográficas (Brasil, 1986/1997)

\begin{tabular}{lccccc}
\hline Ano & Norte (\%) & Nordeste (\%) & Sudeste (\%) & Sul (\%) & Centro-Oeste (\%) \\
1986 & 0,3 & 12,7 & 71,6 & 13,7 & 1,7 \\
1997 & 0,4 & 13,1 & 58,2 & 24,8 & 3,5 \\
\hline
\end{tabular}

Fonte: MTE/Codefat/Datamec; dados trabalhados pela CUT/Desep (1999)

Cabe lembrar ainda que os efeitos desse tipo de reestruturação sobre o setor não parecem de bom augúrio, porque dificultam a adoção de estratégias de competitividade baseadas na qualidade. Como já explicitamos, a competição por custos tende a contaminar o setor, impondo-se de maneira imperiosa sobre o conjunto das empresas, uma vez que dificulta a competição daquelas que buscam qualidade. Conforme esclarece Comin, "as empresas informais acabam roubando espaço das outras, reduzindo escalas, desarticulando cadeias comerciais e financeiras" (Comin, 2000, p. 28).

Esse conjunto de características observadas na análise do desempenho do setor não poderia deixar de ter profundas implicações sobre o trabalho.

Em primeiro lugar, o contínuo processo de terceirização vem expulsando o trabalho das empresas de confecção, concentrando-o cada vez mais nas oficinas de costura, onde abunda o trabalho informal, mal pago, desqualificado, com altas taxas de doenças profissionais 10 e, muitas vezes, a domicílio. Essa tendência se expressa no impressionante crescimento do trabalho informal nos últimos anos, tornando-o praticamente uma regra no setor. Segundo Comin, o emprego formal, "que caiu de aproximadamente 500.000 para 240.000 entre 1990 e 1998, hoje é bem menor do que o informal, estimado em mais de um milhão de pessoas pela principal entidade patronal do setor, a ABIT [Associação Brasileira da Indústria Têxtil]"(Comin, 2000, p. 10).

Em segundo lugar, a análise do trabalho no vestuário não pode ser feita sem considerar a dimensão de gênero, tendo em vista a enorme concentração de mulheres na categoriall. A complexidade dessa questão, entretanto, nos impele a dedicar a ela um tópico em separado.

\section{A dimensão de gênero}

A ampla preponderância do trabalho feminino no setor tem a ver com representações de gênero na sociedade. Conforme vêm elucidando estudos recentes (Abramo, 1997), as imagens de gênero e as supostas capacidades de homens e mulheres que a elas se associam atuam sobre a organização da pro- 
dução e do mercado de trabalho, conferindo-lhes 'lugares' diferenciados na esfera econômica. No caso específico do trabalho na confecção, o tradicional aprendizado da costura como parte da formação das meninas aparece, sem dúvida, como um importante fator na determinação da preponderância feminina no setor. Esse fator apresenta, todavia, um conjunto de conseqüências para o uso que se faz do trabalho feminino na confecção, as quais merecem ser analisadas com mais detalhes.

Por um lado, o fato de o aprendizado de costura ser adquirido informalmente, como parte da socialização feminina, em geral no universo doméstico e não em cursos de formação profissional, confere a esse conhecimento o valor de uma qualidade pessoal da trabalhadora e não de uma qualificação profissional, o que permite aos empregadores conferir baixas remunerações às trabalhadoras, equiparáveis ao trabalho sem qualificação (Kergoat, 1987; Abramo, 1998; Abreu e Sorj, 1994). Por outro lado, o fato de esse trabalho poder ser desempenhado por meio da utilização de máquinas de costura de uso doméstico permite que ele se imbrique com as imagens de gênero e a tradicional divisão das responsabilidades domésticas entre os sexos, ao possibilitar sua execução no domicílio em meio às atividades domésticas, especialmente as de cuidado com os filhos.

Essas particularidades do trabalho de confecção, no contexto de um processo generalizado de terceirização das atividades do setor, acabam por acarretar a multiplicação do trabalho a domicíliol2. Esta só não é maior por causa da perda de controle direto sobre o uso da força de trabalho e a dificuldade de garantia da qualidade que ela acarreta, num quadro de acirramento da competição devido à baixa dinâmica dos mercados.

A segregação das mulheres na cadeia do vestuário se evidencia nas tabelas 4 e 5, que apresentam dados relativos ao emprego, segundo gênero e tamanho da empresa e gênero e faixas de renda. Embora sejam relativos ao conjunto do setor têxtil e de confecção, os dados apontam a discriminação de gênero ao evidenciarem a concentração do trabalho feminino nas menores empresas, bem como a menor remuneração das mulheres em relação aos homens.

Para caracterizar melhor a composição da mão-de-obra do setor e sua distribuição ao longo da cadeia de produção, apresentamos alguns dados de 1999 para o país como um todo, relativos a gênero, raça e escolaridade. Embora aproximados, por se tratar do conjunto do setor têxtil e do vestuário, esses dados fornecem uma visão mais precisa das características que a força de trabalho vem assumindo no atual processo de terceirização. 
Tabela 4

Postos de trabalho, segundo gênero e tamanho do estabelecimento, na indústria têxtil (Brasil - 1999-2001)

\begin{tabular}{|c|c|c|c|c|c|}
\hline Gênero & $\begin{array}{c}\text { Até } 19 \\
\text { empregados }\end{array}$ & $\begin{array}{c}\text { De } 20 \text { a } 99 \\
\text { empregados }\end{array}$ & $\begin{array}{l}\text { De } 100 \text { a } 499 \\
\text { empregados }\end{array}$ & $\begin{array}{l}500 \text { ou mais } \\
\text { empregados }\end{array}$ & Total \\
\hline \multicolumn{6}{|l|}{1999} \\
\hline Masculino & 40.098 & 60.096 & 80.820 & 64.951 & 245.965 \\
\hline Feminino & 121.119 & 127.946 & 89.019 & 57.460 & 395.554 \\
\hline Total & 161.217 & 188.042 & 169.839 & 122.411 & 641.519 \\
\hline \multicolumn{6}{|l|}{2000} \\
\hline Masculino & 45.195 & 68.233 & 85.868 & 74.196 & 273.492 \\
\hline Feminino & 131.087 & 138.966 & 96.028 & 62.521 & 428.602 \\
\hline Total & 176.282 & 207.199 & 181.896 & 136.717 & 702.094 \\
\hline \multicolumn{6}{|l|}{2001} \\
\hline Masculino & 46.861 & 70.027 & 86.005 & 69.247 & 272.140 \\
\hline Feminino & 137.320 & 144.268 & 92.437 & 58.586 & 432.611 \\
\hline Total & 184.181 & 214.295 & 178.442 & 127.833 & 704.751 \\
\hline
\end{tabular}

Fonte: MTE, Relação Anual de Informações Sociais (Rais) — Anuário estatístico (2001)

Tabela 5

Remuneração média nominal em 31/12, em reais, segundo o gênero, na indústria têxtil (Brasil -1999-2001)

\begin{tabular}{|c|c|c|c|}
\hline Gênero & 1999 (R\$) & $2000(\mathrm{R} \$)$ & 2001 (R\$) \\
\hline Masculino & 595,74 & 606,78 & 665,21 \\
\hline Feminino & 348,80 & 365,51 & 400,10 \\
\hline
\end{tabular}

Fonte: MTE, Relação Anual de Informações Sociais (Rais) — Anuário estatístico (2001)

\section{A "cara" da terceirização}

No que se refere ao gênero, os dados indicam que o setor é tipicamente feminino, já que as mulheres constituem 63,9\% da mão-de-obra, enquanto os homens correspondem a apenas $36,1 \%$. No entanto, quando se comparam esses dados com a distribuição da mão-de-obra entre os tipos de vínculo, observa-se que os homens tendem a se destacar entre os assalariados com carteira assinada (correspondendo a 38,1\% do total dos trabalhadores com esse tipo de vínculo), ao passo que as mulheres se concentram proporcionalmente mais entre os assalariados sem carteira assinada (correspondendo a $70,4 \%$ dos trabalhadores com esse tipo de vínculo) e entre os trabalhadores por conta própria (dos quais correspondiam a 69,2\%) 13 , como indicado na tabela 6 . 
Tabela 6

Distribuição dos empregados da indústria têxtil e do vestuário, segundo posição na ocupação e no gênero (Brasil - 1999)

\begin{tabular}{lccc}
\hline Posição na ocupação & Masculino (\%) & Feminino (\%) & Total (\%) \\
Assalariado com carteira & 38,1 & 61,9 & 100,0 \\
Assalariado sem carteira & 29,6 & 70,4 & 100,0 \\
Trabalhador por conta própria & 30,8 & 69,2 & 100,0 \\
Empregador & 45,0 & 55,0 & 100,0 \\
Total & 36,1 & 63,9 & 100,0 \\
\hline
\end{tabular}

Fonte: IBGE; dados trabalhados pela CUT/Desep (2001)

Também no que diz respeito à raça, os dados indicam uma situação desigual, especialmente entre brancos e pardos: enquanto os brancos apresentam uma concentração proporcionalmente maior entre os trabalhadores com carteira, os pardos se concentram especialmente entre os trabalhadores por conta própria e os assalariados sem carteira, conforme atestam os dados da tabela 7.

Tabela 7

Distribuição dos empregados da indústria têxtil e do vestuário, segundo posição na ocupação e identidade étnico-racial (Brasil - 1999)

\begin{tabular}{lccccc}
\hline Posição na ocupação & Branca (\%) & Parda (\%) & Preta (\%) & Amarela (\%) & Total (\%) \\
Assalariado com carteira & 60,7 & 34,8 & 4,3 & 0,2 & 100,0 \\
Assalariado sem carteira & 56,4 & 40,1 & 3,2 & 0,2 & 100,0 \\
Trabalhador por conta própria & 40,9 & 55,3 & 3,8 & 0,0 & 100,0 \\
Empregador & 86,0 & 13,2 & 0,0 & 0,8 & 100,0 \\
Total & 59,8 & 36,2 & 3,8 & 0,2 & 100,0 \\
\hline
\end{tabular}

Fonte: IBGE; dados trabalhados pela CUT/Desep (2001)

Convém destacar ainda que a discriminação étnica vem ganhando novos contornos com o emprego de grande número de recém-chegados (especialmente mulheres), sobretudo da Bolívia, que, por não disporem de documentação regular, não têm outra forma de inserção no mercado de trabalho a não ser o trabalho ilegal. Há um abuso da situação irregular desses trabalhadores, em geral por seus próprios compatriotas, que montam verdadeiras redes de exploração desse tipo de trabalho (O Estado de São Paulo, 18/ 03/2001). Muitas vezes, esses imigrantes vieram para o Brasil a fim de juntar dinheiro e voltar a seu local de origem, mas, frente à realidade que encontram, não conseguem mais sair do país. 
Segundo reportagem da Folha de São Paulo (2003), existiriam atualmente na Grande São Paulo cerca de 18 mil oficinas de costura clandestinas, movimentadas pelo trabalho de imigrantes coreanos e latino-americanos - especialmente bolivianos, paraguaios, peruanos, colombianos e chilenos. Vale assinalar que o trabalho nessas oficinas se caracteriza não só pelo pagamento irrisório e péssimas condições em que é exercido, mas também por práticas de escravização, freqüentemente denunciadas pela imprensa (Amorim, 2003, pp. 53-54).

Finalmente, quanto à escolaridade, os dados indicam que o setor é composto principalmente por trabalhadores com escolaridade básica, já que $53 \%$ da mão-de-obra possui até sete anos de instrução formal. A baixa escolaridade se concentra, entretanto, entre os trabalhadores por conta própria $(80,5 \%$ dos quais possui apenas a escolaridade básica) e os assalariados sem carteira (63,5\% dos quais se encontram nesse nível de escolaridade). Os assalariados com carteira se destacam pela mais baixa concentração de trabalhadores nesse nível de escolarização (apenas 48,7\%), como verificado na tabela 8 .

Tabela 8

Distribuição dos empregados da indústria têxtil e do vestuário, segundo posição na ocupação e instrução formal (Brasil — 1999)

\begin{tabular}{lcccccc}
\hline Posição na ocupação & Até 3 anos & $\mathbf{4}$ a 7 anos & $\mathbf{8}$ a 10 anos & $\begin{array}{c}11 \text { anos } \\
\text { ou mais } \\
(\%)\end{array}$ & $\begin{array}{c}\text { Sem } \\
\text { declaração } \\
(\%)\end{array}$ & $\begin{array}{c}\text { Total } \\
\text { (\%) }\end{array}$ \\
\hline Assalariado com carteira & 7,9 & 40,8 & 27,3 & 22,9 & 1,0 & 100,0 \\
Assalariado sem carteira & 16,3 & 47,2 & 21,3 & 14,0 & 1,1 & 100,0 \\
$\begin{array}{l}\text { Trabalhador por } \\
\text { conta própria }\end{array}$ & 53,5 & 27,0 & 09,4 & 10,1 & 0,0 & 100,0 \\
Empregador & 03,1 & 20,9 & 19,4 & 55,8 & 0,8 & 100,0 \\
Total & 13,1 & 39,9 & 24,0 & 22,1 & 1,0 & 100,0 \\
\hline
\end{tabular}

Fonte: IBGE; dados trabalhados pela CUT/Desep (2001)

Essa análise da composição da força de trabalho nos permite concluir que a indústria têxtil e do vestuário vem adotando largamente o uso da mão-de-obra barata como estratégia de competitividade, com ênfase na utilização de trabalhadores que se concentram nas oficinas de costura e no trabalho a domicílio, onde abunda o trabalho sem carteira assinada e por conta própria. Entre eles, destaca-se uma alta porcentagem de mulheres, pardos e pessoas de menor grau de instrução extremamente mal remunerada, que, como assinala a análise do Desep, "funcionou como o meio privilegiado de efetivação de uma competitividade 'espúria' que sustentou boa parte da indústria nos anos recentes" (CUT/DESEP, 2001, p. 14). 


\section{A cadeia}

A cadeia típica do vestuário pode ser representada como indicado no gráfico 2. Contudo, embora esse seja o formato mais comum da cadeia no setor, os arranjos existentes podem ser muito variados. Como a pesquisa evidenciou, nem sempre as empresas líderes são as distribuidoras de confecção (cadeia A); por outro lado, conforme evidencia o exemplo da confecção 2, há um movimento das empresas de confecção detentoras de marca no sentido de se dedicarem cada vez mais à distribuição.

\section{Gráfico 2}

Cadeia típica do vestuário

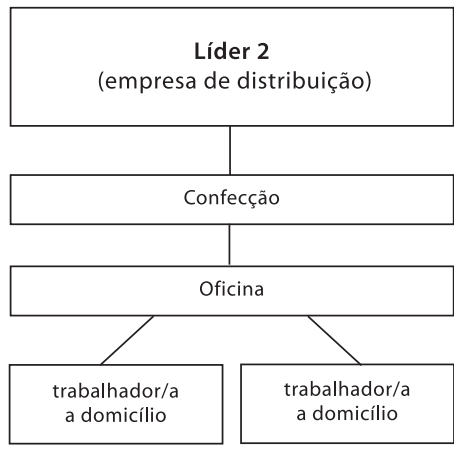

Diferentemente de outros setores, a empresa que comanda a cadeia não se encontra, em geral, na produção, mas na distribuição. É a partir dessa empresa que se iniciam os pedidos para a cadeia de produção. Geralmente, as grandes distribuidoras definem as tendências da moda por meio da escolha de temas (coleções), a partir dos quais são organizados os pedidos (configuration order) às empresas de confecção. As configuration orders constituem as especificações de cada modelo (número de peças, por tamanho, para cada ponto de venda). A partir dessa especificação é que as confecções começam o trabalho de modelagem. O importante a destacar nesse arranjo é que ele implica, geralmente, que o desenho seja desenvolvido pelas distribuidoras, o que permite a estas deter a parcela mais importante do P\&D do setor.

Como bem assinalado por Tomei (1999), um aspecto a destacar nessa relação dos distribuidores com os produtores é a dissociação entre a produção e as etapas do desenho e da comercialização do produto. O controle dessas 
duas atividades fundamentais do processo de realização das mercadorias do setor pelos distribuidores gera uma subordinação muito grande dos produtores. Conforme sublinha Tomei (1999, p. 9), “é a empresa que vende e distribui bens que levam sua marca, ainda que não participe de sua fabricação, a que estabelece de antemão as características do produto, os procedimentos de produção e a tecnologia a utilizar-se, entre outras coisas, e que decide sobre a continuidade em uma mesma região ou país, da produção".

As empresas de confecção, nesse sentido, são as responsáveis pela produção. Mas, como em geral elas não vendem diretamente para o mercado, e sim para uma rede de distribuição, sua produção é determinada pelos distribuidores. Elas se encontram, dessa forma, ensanduichadas entre duas redes poderosas: a varejista e a fornecedora de matéria-prima (tecido). Com as fornecedoras de tecido, a negociação é muito difícil, porque as empresas desse setor têm muitas opções de venda, inclusive ligadas à exportação, devido à qualidade que vêm alcançando em seus produtos; com as redes de distribuição, tampouco é possível negociar, tendo em vista a assimetria de poder: enquanto estas últimas são, em geral, grandes empresas nacionais e multinacionais, as confeccionistas têm porte médio e pequeno capital. Além disso, como não têm acesso direto ao mercado, ficam muito dependentes de seus clientes, que as pressionam continuamente no que se refere aos preços, por causa da acirrada concorrência que domina o mercado.

Frente à dificuldade de negociação com o fornecedor e o cliente, as empresas de confecção se vêem na contingência de economizar onde é possível, ou seja, na produção. Isto explica não só o profundo processo de terceirização que vem dominando o setor, mas sobretudo o sentido desse processo, voltado mais para a busca incessante do rebaixamento de custos do que da elevação da qualidade.

Na verdade, o que acontece é que, frente à enorme pressão dos magazines sobre a produção14, essas empresas estão partindo para uma busca desenfreada da flexibilização, por meio da terceirização, já que ela as torna mais adequadas a essa realidade: como a produção não é mais interna, quando há suspensões repentinas de pedidos, pode-se simplesmente não encaminhá-los às oficinas e com isso não pagar a mão-de-obra; quando a produção é interna, esse procedimento não é possível. Nesse contexto, as empresas de confecção estão concentrando internamente apenas o molde, o corte e algumas partes mais complexas da costura. Quanto às demais, são encaminhadas às oficinas de costura para serem montadas.

As oficinas (ou facções) 15 formam, portanto, o segundo nível da cadeia de produção e estão submetidas a uma divisão de trabalho no conjunto da cadeia que lhes relega apenas o trabalho mecânico de montagem de peças já concebidas, testadas e cortadas nas empresas de confecção. A divisão de trabalho que se estabelece, dessa forma, entre as empresas de confecção e as ofi- 
cinas é uma típica divisão taylorista: o trabalho de concepção se concentra nas primeiras 16 - que poderiam ser chamadas, para usar uma conceituação de Castillo e Santos (1993), de empresas-cabeça - enquanto as últimas (que poderiam ser chamadas de empresas-mão) se restringem a executar o trabalho repetitivo de montagem de um enorme conjunto de peças iguais.

As oficinas de costura compõem um amplo leque de pequenas empresas. Esse leque vai desde empresas com produção significativa, que contam com 30 a 40 costureiras, têm máquinas de primeira geração, chegam a fechar de 200 a 500 peças por dia na alta estação, são legalizadas e têm empregados registrados, até empresas muito pequenas, com apenas quatro ou cinco máquinas, em fundos de quintal, e sem qualquer tipo de registro ou formalização de seus trabalhadores. É neste nível, portanto, que se encontra uma ampla difusão do trabalho sem registro. É também nesse nível que vêm se proliferando as cooperativas, as quais, longe do modelo associativo inspirador da proposta de trabalho cooperativado no século XIX, vêm se baseando, nesse caso, em trabalho assalariado disfarçado, sem direitos trabalhistas (Lima, 1998, 1999 e 2002; Amorim, 2003). É importante destacar que o movimento de difusão dessas "cooperativas de empresas" foi facilitado pela alteração do artigo 442 da CLT, em 1994, a partir da qual se estabelece a prescindibilidade de vínculo empregatício nas organizações cooperativistas.

A partir da mudança legal, essas cooperativas começam a se difundir, ao se tornarem, como sublinha Amorim,

\footnotetext{
"uma alternativa de subcontratação capaz de oferecer, além das mesmas vantagens obtidas no trabalho domiciliar, a possibilidade do emprego de maquinários modernos, ausentes ou difíceis de serem instalados em um domicílio, bem como o controle direto do serviço realizado pelas trabalhadoras" (Amorim, 2003, p. 200; grifos nossos).
}

O quadro de pressão por preço e de flexibilização se completa com o terceiro nível da cadeia de produção — o trabalho a domicílio - , onde a norma do pagamento por peça facilita enfrentar as flutuações do mercado e a total dependência das costureiras em relação às oficinas que lhes repassam o trabalho permite pagar valores extremamente baixos por peça montada. A maneira como as oficinas de costura se relacionam com as trabalhadoras a domicílio busca a garantia de um estrito controle sobre seu trabalho: como, em geral, é a oficina que fornece a máquina à trabalhadora, isso permite à oficina uma enorme capacidade de pressão sobre esta, com a ameaça de retirada da máquina. Mas, mesmo nos casos em que a máquina é da própria trabalhadora, a enorme oferta desse tipo de trabalho torna as trabalhadoras a domicílio muito dependentes daqueles que lhes fazem chegar o trabalho, sejam as oficinas, sejam as confecções. 
Algumas vezes, entre a trabalhadora a domicílio e a confecção, ou entre a trabalhadora e a oficina, se interpõe a figura de intermediadores de mãode-obra, cuja função é apenas distribuir o trabalho entre um conjunto de trabalhadoras a domicílio. Eles buscam as peças cortadas nas empresas, as distribuem de casa em casa entre as trabalhadoras, as recolhem ao término do trabalho e as entregam de volta às oficinas ou empresas de confecção.

Cumpre observar ainda que a separação entre o segundo e o terceiro níveis da cadeia nem sempre é muito nítida: muitas das pequenas oficinas de fundo de quintal se confundem com o trabalho a domicílio, tendo em vista que são familiares e agregados que trabalham no próprio domicílio para outras oficinas ou para empresas de confecção em troca de pagamento por peça. Todavia, a propriedade da máquina pelos próprios trabalhadores ou por um membro da família que emprega os demais pode criar relações de trabalho bastante diferenciadas.

\section{As confeccionistas}

A primeira questão a destacar nas empresas de confecção é o profundo processo de terceirização que as vem marcando. A reestruturação dessas empresas tem passado muito pouco por um processo de inovação tecnológica e organizacional, concentrando-se de maneira mais evidente na terceirização. Além das dificuldades, já abordadas, de negociação, ao mesmo tempo, com os distribuidores e fornecedores de matéria-prima, há outro ponto a salientar na realidade dessas empresas: $80 \%$ do custo da produção se concentram no pagamento da mão-de-obra utilizada no trabalho de costura.

A terceirização tem sido utilizada, nesse contexto, como recurso para rebaixar custos. Ao terceirizar para firmas pequenas, o custo de produção diminui muito, porque elas podem trabalhar com carga tributária muito menor como microempresas ou cooperativas, ou ainda simplesmente por não registrarem seus funcionários. Como esclarece o entrevistado abaixo:

“O valor do produto comprado pronto é por volta da metade do que eu gasto para produzi-lo internamente. Aqui tem a capacidade instalada; produzindo ou não, a capacidade está aqui. O mês em que eu não corto o mesmo número de peças, eu tenho que pagar os funcionários do mesmo jeito; já com a oficina, se eu não preciso do produto, eu simplesmente não encaminho as peças para ela e não tenho que pagar nada". (Gerente da confecção 2)

Outro problema do setor, que agrava a situação para as empresas, é que a indústria da confecção tem uma produção muito sazonal: produz-se muito nos meses que antecedem o Natal e o inverno. Como explicita um dos geren- 
tes entrevistados: “a entressafra é um horror; em janeiro, fevereiro, agosto, setembro e outubro, simplesmente não se produz nada".

É neste quadro que se inserem as iniciativas de terceirização que vêm marcando profundamente o setor e que são responsáveis por um enorme enxugamento da mão-de-obra nas empresas de confecção e sua difusão nas oficinas. Essa tendência se expressa claramente no comportamento do emprego nas três empresas pesquisadas: a confecção 1 diminuiu sua mão-de-obra de mais de 200 trabalhadores, em 1995, para 85, em 2000, embora a produção tenha se mantido mais ou menos estável; a confecção 2 baixou esse número de 500 para 180, no mesmo período; e a confecção 3, embora tenha aumentado o número de funcionários de 50 para 80, devido a um grande crescimento nesses anos, trabalha no total com cerca de 430 pessoas - 350, portanto, externas à fábrica.

Destaque-se, também, que o processo de externalização continua em andamento, conforme corroboram as palavras a seguir: "O plano é terceirizar tudo. Nós vamos praticamente acabar com a fábrica no ano que vem. Vamos ficar só com o desenvolvimento do molde. A fabricação vai ser totalmente externalizada". (Gerente da confecção 2; grifos nossos) A visita a essa empresa nos surpreendeu pela imagem chocante de uma fábrica-fantasma. Tratava-se de um enorme prédio de quatro andares, praticamente vazio, situado em meio ao bairro de Campos Elíseos, em São Paulo. Salvo o setor de modelagem, onde se encontravam aproximadamente meia dúzia de máquinas de costura e uma fileira de mais de dez máquinas de corte, a fábrica possuía imensos espaços desocupados, entremeados por estantes - a maior parte também vazias e umas poucas com roupas estocadas. A área mais povoada da fábrica se encontrava em um canto de um dos andares, onde se instalou o setor de distribuição, com uma fileira de quase $20 \mathrm{compu}-$ tadores, através dos quais se fazia o controle da expedição das peças para as oficinas, o recebimento das roupas confeccionadas e a distribuição para as lojas 17 .

Convém destacar, ainda, que, mesmo para os trabalhadores internos, as condições de trabalho encontradas nessas fábricas estão muito longe de serem consideradas satisfatórias: os salários das costureiras são baixos, em geral muito próximos do piso, por volta de $\mathrm{R} \$ 450,00$, em média (o piso em São Paulo é de R\$ 357,00); as taxas de rotatividade são razoavelmente altas (entre 20 e $25 \%$ ao ano); os treinamentos são extremamente escassos (das três empresas, apenas a confecção 2 declarou investir em treinamento, mas esse investimento não chega a $0,5 \%$ do faturamento da empresa e vem diminuindo nos últimos anos); e os benefícios são também pouco significativos, resumindo-se aos aspectos legais (creche e vale-transporte). Observe-se que nenhuma delas fornece assistência médica ou odontológica e que a única empresa que forneceu participação nos lucros e rendimentos (confecção 
2) o fez por um curto período de tempo, embora se deva destacar que a confecção 1 e a confecção 3 fornecem vale-refeição.

Também no que se refere à organização do trabalho, as inovações são pouco significativas. De acordo com um ex-dirigente de um grande magazine, que está no momento abrindo uma fábrica de confecção, a forma de organização da produção predominante nas empresas ainda é baseada na divisão e na organização do trabalho em linhas. Apenas algumas poucas grandes empresas estão mudando para a organização em células de produção, em que cada célula é responsável pela confecção de um tipo de peça. O problema, segundo o entrevistado, é a sincronização das células, o que exige a utilização de $\mathrm{CAD} / \mathrm{CAM}^{18}$, ainda muito pouco difundido entre as empresas do setor.

Nas empresas visitadas, a organização do trabalho seguia o mais clássico princípio taylorista: cada trabalhador fazia uma parte bastante pequena do processo; na confecção 1, por exemplo, alguns trabalhadores costuravam a bolsa, outros pregavam a alça, outros pregavam um botão de pressão, outros viravam a bolsa depois de costurada do avesso para o direito, outros cortavam os fios e tiravam as rebarbas de costura. Foi encontrada, entretanto, certa preocupação com a multifuncionalidade, que se expressava em iniciativas de treinar as costureiras nas diferentes tarefas e máquinas (por exemplo, na máquina reta e de braço), de forma a garantir certa flexibilidade, especialmente nos momentos de alta da produção. Observe-se, todavia, que tal multifuncionalidade se atém às atividades de costura, parecendo muito restritas as oportunidades de carreira na profissão, já que o corte e a modelagem são atividades que exigem um profissional com outro tipo de formação e experiência.

Finalmente, um último ponto a destacar nesse processo de reestruturação se refere às implicações das transformações no que diz respeito à divisão sexual do trabalho. A deterioração das condições de trabalho e de emprego que a modernização do setor vem provocando não pode ser compreendida sem se levar em conta que ela se imbrica de maneira extremamente forte com a divisão sexual do trabalho. Com efeito, ao lado da externalização do trabalho das empresas de confecção, observa-se a expulsão das mulheres desse nível da cadeia de produção, onde elas começam a ser substituídas pelos homens, e sua concentração nas oficinas e no trabalho a domicílio, onde é evidente a precarização das condições de trabalho e do vínculo empregatício. A confecção 2 é um exemplo significativo desse processo: em 1995, a empresa tinha 500 trabalhadores, dos quais $80 \%$ eram mulheres; hoje, dos 180 que ficaram, cerca de $60 \%$ são homens. 


\section{As oficinas de costura}

Foram investigadas seis oficinas de costura, que, de certa forma, abrangem o amplo espectro de situações que essas empresas preenchem: de fato, elas variam de oficinas regularizadas em termos legais, com 40 trabalhadores oficialmente registrados (oficina 4), até pequenas empresas de fundo de quintal com sete trabalhadores (oficina 5), que trabalham sem registro, numa situação muito próxima à do trabalho a domicílio.

As situações de precarização aí encontradas são bastante evidentes, a começar pelo aparecimento do trabalho sem registro, como forma de enfrentamento da flutuação do trabalho. Embora muitas oficinas trabalhem com mão-de-obra registrada, a pesquisa se deparou com uma utilização razoavelmente difundida do trabalho não protegido. Os arranjos aí são os mais diferentes possíveis. Desde as oficinas que não registram nenhum dos funcionários (como as 3 e 5), até aquelas que registram todos (oficinas 4 e 6), aquelas que trabalham ao mesmo tempo com funcionários registrados e não registrados (oficina 2), passando ainda pelo caso de uma oficina que tinha 30 funcionários registrados (oficina 1), mas que estava rompendo o contrato com eles, porque o dono precisava de recursos para terminar a construção de um galpão maior, para onde pretendia mudar a produção (que funcionava até então em três cômodos da casa do sogro, situada no mesmo terreno de sua casa). Outra situação comum é o hábito de chamar trabalhadores a domicílio para trabalhar na oficina em épocas de maior produção.

Para os trabalhadores que são contratados, a média salarial é um pouco inferior aos valores praticados nas empresas de confecção, não chegando, em geral, a R \$ 400,00 por mês. Para os não contratados, o pagamento é por peça montada; embora cheguem a receber mais do que os contratados, eles sofrem de maneira muito mais séria o problema da flutuação da produção, pois o setor fica quase cinco meses por ano praticamente sem trabalho, época em que eles podem chegar a não receber qualquer remuneração.

De fato, as condições de trabalho, em geral, são bastante inferiores quando comparadas às encontradas nas empresas de confecção: a rotatividade da mão-de-obra é muito maior, não há praticamente treinamento, e o único tipo de benefício encontrado, além do vale-transporte (obrigatório por lei), foi o café da manhã (oficinas 2, 3 e 4). Observe-se que nem sequer a norma legal de auxílio-creche é observada pela oficina 4, que tem mais de 29 trabalhadoras registradas.

Foram também encontradas condições de trabalho extremamente inadequadas, em especial nas oficinas adaptadas em cômodos das casas de seus proprietários: salas mal iluminadas, máquinas apinhadas e distribuídas pelos vários cômodos 19 , ventilação insuficiente, ausência de refeitório e local de trabalho inadequado (trabalhadores sentados no chão ou sobre a mesa). 
Na verdade, o trabalho nessas oficinas se confunde com o trabalho a domicílio: trabalho autônomo, com pagamento por peça e sazonal, com a única diferença de que, em vez de se desenvolver na moradia do trabalhador, é executado na moradia do empregador. Mesmo nas oficinas que funcionam em locais próprios para a produção, encontramos locais de trabalho desorganizados, com iluminação e ventilação deficientes e máquinas amontoadas (oficina 6). À exceção das oficinas 4 e 2, que possuíam espaços mais apropriados e equipamentos mais modernos, as condições de trabalho encontradas se mostraram extremamente precárias e inadequadas.

Finalmente, quanto à organização do trabalho, as oficinas acompanhavam, de forma geral, os princípios tayloristas encontrados nas confecções: as peças passam pela mão de vários funcionários, cada qual responsável por uma parcela do trabalho - costura na máquina reta, costura na máquina de braço, overloque, pespontadeira, sem contar o trabalho das ajudantes que cortam os fios, passam as peças prontas, embalam, etc. Apenas a oficina 2 trabalha com células, cada uma responsável pela fabricação total de um modelo. O dono declarou, entretanto, que esse tipo de organização nem sempre é possível, por causa da constante variação dos modelos.

$\mathrm{O}$ material encontrado traz à tona uma relação entre as confeccionistas e as oficinas que parece repetir a das distribuidoras com as confecções: relações baseadas numa grande assimetria de poder e no estabelecimento de vínculos informais que permitem às primeiras exercer uma grande pressão sobre as segundas por custos e prazos ${ }^{20}$. Mas, se o controle das grandes distribuidoras sobre as empresas de confecção permite garantir condições mais adequadas de trabalho nesse nível, o mesmo não acontece na relação entre essas últimas e as oficinas. Como esclarece a declaração abaixo:

“A distribuidora X trabalha com aproximadamente 500 confeccionistas que são estreitamente controladas por ela; mas ela não controla a cadeia para trás. Nesse nível, a única coisa que acontece é que, se algum gerente tiver conhecimento de trabalho irregular na cadeia, ele tem que trocar de fornecedor; mas o trabalho sem registro não é considerado irregular; trabalho irregular é apenas o infantil e o escravo." 21 (Ex-gerente da distribuidora de confecções)

Nesse contexto, a pressão por custo incide fortemente sobre as condições de trabalho nas oficinas, entre as quais abundam situações de irregularidade do trabalho e, freqüentemente, das próprias empresas (que não têm nem sequer registro como pessoa jurídica). Embora muitas confeccionistas só trabalhem com oficinas regulamentadas, esse preceito está longe de ser a regra no setor.

Vale lembrar que a falta de regularização, muitas vezes, prejudica as próprias oficinas, uma vez que a informalidade facilita o descumprimento 
de compromissos, especialmente para aquelas que trabalham para os intermediadores de mão-de-obra. Como explicita Tomei:

“os intermediários garantem, a custos e riscos reduzidos para a empresa, a produção das diferentes peças, o controle de qualidade e a montagem das mesmas no produto final. Não se pode perder de vista, entretanto, que a atividade dos intermediários obedece também à lógica da desarticulação de um vínculo direto entre o trabalhador e a empresa com vistas a diluir ou eliminar qualquer obrigação ou responsabilidade social dessa última" (Tomei, 1999, p. 37).

Os comentários a seguir são bastante esclarecedores a respeito dos problemas que comumente ocorrem com as oficinas que trabalham com os intermediadores:

“O problema é que o pagamento em geral não é à vista; o prazo varia entre $15 \mathrm{e}$ 45 dias, e aí acontece que, quando você vai lá buscar o cheque, a loja mudou de nome e o seu fulano não está mais lá. Isso já aconteceu comigo" (proprietária da oficina 5).

“Essas empresas funcionam como verdadeiros gigolôs da costura. Elas não fazem nada; só exploram o trabalho alheio e, às vezes, há muita malandragem. Tem empresa que, quando a gente entrega as peças, eles dão uma nota para gente cobrar depois de tantos dias e no final a nota é falsa; às vezes, dão cheques sem fundo" (proprietário da oficina 6).

"Às vezes, depois de você entregar a mercadoria, eles falam que simplesmente não vão pagar porque o trabalho não está bom e a gente fica sem ter o que fazer" (proprietária da oficina 5).

Esse tipo de problema é sentido pelas oficinas em geral, que buscam trabalhar diretamente com os confeccionistas como forma de se proteger das artimanhas dos intermediadores: "Eu, felizmente, só trabalho com o fabricante, porque trabalhar com o intermediador é problema na certa" (proprietário da oficina 2). O problema é que, como a concorrência entre elas é acirrada, muitas oficinas não conseguem se inserir diretamente na cadeia, acabando por ficar inevitavelmente nas mãos dos intermediadores.

Outro grande problema das oficinas é que elas não têm a quem recorrer. Por um lado, a informalidade dificulta a proteção legal; por outro, elas não dispõem de sindicatos nem associações que as protejam e têm dificuldade de se unir no quadro de acirrada concorrência que predomina no mercado. Embora algumas oficinas apresentem um nível maior de profissionalização e uma preocupação mais efetiva com a competitividade, que se expressa em investimentos em maquinaria, a pressão por rebaixamento de custos é constante, o que as expõe a uma grande instabilidade. 
Uma das estratégias utilizadas pelas confecções para rebaixar ainda mais o custo é buscar oficinas na periferia da cidade, onde, em geral, se paga menos pela mão-de-obra. Essa política - assim como a de desconcentração da produção no Sudeste do país — vem acarretando uma mudança importante na geografia do setor, que se expressa na grande diminuição da concentração das oficinas nos bairros centrais, como Barra Funda, Bom Retiro e Campos Elíseos, e na sua difusão para a periferia da cidade.

\section{O trabalho a domicílio}

O trabalho a domicílio não é novidade no setor da confecção. Muitos estudos têm sublinhado que esta prática acompanha o setor desde sua constituição, antecedendo largamente a reestruturação produtiva que vem acompanhando o atual processo de globalização econômica.

Já em 1986, Abreu assinalava a extensão do trabalho a domicílio, chamando a atenção para o fato de que sua sobrevivência tinha pouco a ver com questões relacionadas a um suposto "atraso" do setor e muito mais com as relações de gênero na sociedade e com a divisão sexual das tarefas domésticas (Abreu, 1986). Com efeito, numa sociedade onde cabe exclusivamente ao sexo feminino a responsabilidade das tarefas domésticas, é compreensível que as mulheres busquem trabalhos que possam ser desenvolvidos no espaço domiciliar, viabilizando sua execução concomitantemente ao desempenho das tarefas relacionadas ao cuidado com a casa, com a alimentação familiar e com os filhos.

Esse tipo de relação seria confirmada em pesquisa de Abreu e Sorj (1994), em que se discutem as diferentes relações de subcontratação presentes no setor de confecção no Rio de Janeiro, de acordo com o gênero dos trabalhadores. Esse estudo ressalta que o trabalho subcontratado de confecção apresenta diferentes características conforme seja desenvolvido por homens ou mulheres. Tais características estão profundamente condicionadas pela divisão sexual das tarefas domésticas: no caso dos homens, mantém-se, em geral, a separação entre local de trabalho e domicílio, com uma visão mais profissional da atividade por parte dos trabalhadores, o que o torna mais identificado com um trabalho por conta própria; já no caso das mulheres, o trabalho é realizado no domicílio, como forma de adequá-lo ao tempo e ao espaço doméstico, e a relação de trabalho assume características mais próximas das relações típicas de emprego, com uma grande subordinação das costureiras em relação ao contratante do trabalho.

Essas questões não podem ser deixadas de lado na análise do trabalho a domicílio, uma vez que são fundamentais à compreensão de como as atuais tendências de terceirização do setor se somam a uma realidade da divisão 
sexual do trabalho em nossas sociedades que torna especialmente as mulheres casadas e com filhos uma clientela disponível para esse tipo de emprego. É só a partir delas que se podem compreender “as razões que levam esse grupo de mulheres a estar disponível para o mercado de trabalho a domicílio" (Abreu e Sorj, 1994, p.149), apesar de suas características aparentemente pouco atrativas: baixo nível de remuneração, ausência de garantias trabalhistas e produção sazonal.

Em pesquisa mais recente, Nunes Filho encontrou que o estado civil não emergiu como fator relevante para a disposição ao trabalho a domicílio. De acordo com seu estudo, "o que prende a mulher ao trabalho industrial a domicílio está muito mais afeto a sua condição de mãe do que de esposa" (Nunes Filho, 2002, p. 251). Apesar do pequeno número de trabalhadoras a domicílio pesquisadas em seu estudo (dez mulheres), é bastante provável que esse achado se deva a uma mudança importante de padrão na constituição e nos hábitos familiares, com a maior inserção da mulher no mercado de trabalho e o aumento da responsabilidade feminina pela chefia da casa. O importante a destacar nesse quadro é que, casadas ou não, acompanhadas ou não de seus maridos, companheiros ou pais de seus filhos, essas mulheres se encontram como responsáveis exclusivas pelo cuidado das crianças, indicando que a tradicional divisão dos papéis masculinos e femininos, no que se refere à esfera da reprodução social, continua operando.

Esse conjunto de questões nos coloca, dessa forma, diante de uma realidade em que às predisposições que sempre existiram para a utilização do trabalho feminino a domicílio vem se somar a intensa busca de flexibilização do trabalho que caracteriza o setor no momento atual. Quanto a esta questão, vale lembrar que a subcontratação de trabalho a domicílio pelas oficinas de costura faz parte da mesma lógica que leva as empresas de confecção a externalizar a costura para as oficinas, ou seja, a busca de economia com mão-de-obra. Seja se eximindo do contrato de trabalho e das obrigações sociais correspondentes, seja pagando às trabalhadoras a domicílio valores inferiores, pelas peças costuradas, aos pagos à mão-de-obra que trabalha internamente, as oficinas buscam o trabalho a domicílio como forma de rebaixar os custos com mão-de-obra. Conforme explicita Tomei, "o que sucede de fato é uma transferência de riscos e custos de um nível a outro da cadeia destas relações interfirmas e entre estas e outros agentes econômicos" (Tomei, 1999, p. 37).

O trabalho a domicílio das costureiras se insere, portanto, nessa lógica perversa de um setor que baseia sua competitividade numa estratégia marcada pela grande exploração da mão-de-obra que caracteriza a disputa dos mercados assentada basicamente nos preços. Entretanto, ele não pode ser entendido sem se considerar a disponibilidade de um grupo de mulheres para esse trabalho, a qual parece estar relacionada a dois fatores: por um la- 
do, a dificuldade de inserção no mercado de trabalho para mulheres de meia-idade e com filhos pequenos, que possuem uma qualificação específica, mas pouca escolaridade; por outro, a preferência dessas mulheres pelo trabalho a domicílio, em função da divisão sexual das tarefas domésticas. Este dado, encontrado numa ampla variedade de estudos sobre o tema (Abreu e Sorj, 1994; Araújo e Amorim, 2000; Tomei, 1999; Lavinas et al., 1998) e corroborado por nossa pesquisa, se explica a partir da flexibilidade de distribuição das tarefas ao longo do dia que o trabalho a domicílio permite. Isto possibilita entremeá-las com o trabalho doméstico, como esclarece uma de nossas entrevistadas:

“Eu prefiro trabalhar em casa porque posso fazer o meu horário, tenho mais liberdade. Se eu fosse solteira, valia a pena trabalhar na oficina, porque acabaria ganhando mais, mas, como eu sou casada e tenho filhos, acho que é melhor em casa". (trabalhadora a domicílio entrevistada em junho de 2001)

Entretanto, essa liberdade nem sempre é real, tendo em vista as pressões contínuas quanto ao cumprimento de prazos. Como esta questão é central na indústria da confecção, essas trabalhadoras, em geral, têm que cumprir prazos muito curtos, o que lhes exige esforços que certamente interferem em sua vida doméstica, quando não em suas condições de saúde. As declarações que se seguem são esclarecedoras a esse respeito:

\footnotetext{
“Não tem um horário certo de trazer o serviço. Ontem mesmo, o X (contratante) trouxe às seis horas da tarde pra entregar hoje de manhã, esse que você viu a gente colocando no carro". (trabalhadora a domicílio entrevistada em agosto de 2001) “O prazo de entrega é sempre determinado por ele (contratante) e não tem regularidade: o material pode chegar de manhã, de tarde, de noite e ser para o dia seguinte. Se a gente não cumpre os prazos, ele pune a gente diminuindo ou até tirando o serviço". (trabalhadora a domicílio entrevistada em agosto de 2001)
}

Esse tipo de pressão merece alguns comentários, tendo em vista os efeitos perversos sobre a vida dessas mulheres, que vão muito além da carga de trabalho abusiva que muitas vezes têm que enfrentar. Em primeiro lugar, ele é uma expressão das inúmeras formas de controle sobre o trabalho que os contratantes utilizam como estratégia para mitigar o fato de não poderem exercer o controle direto sobre o uso da força de trabalho. Nesse sentido, ele faz parte de um conjunto de procedimentos adotados pelos contratantes para garantir esse controle. Tais práticas vão desde a propriedade da máquina até a não aceitação da encomenda quando julgam que a qualidade não está em conformidade com o pedido, o que significa simplesmente o não pagamento pelo trabalho realizado. Embora estes sejam procedimentos mais ex- 
tremos, são utilizados com freqüência, ao lado das constantes ameaças de não oferecerem mais trabalho. Em segundo lugar, essa pressão favorece a utilização de familiares no trabalho, sobretudo filhos menores, tornando-se um incentivo ao trabalho infantil. Esse problema, fonte de constantes denúncias do Sindicato, foi corroborado por nossa pesquisa, que também se deparou com a utilização do trabalho de filhos menores por parte das trabalhadoras a domicílio.

Apesar do emprego de todas essas estratégias, a impossibilidade de um controle mais direto sobre o trabalho das costureiras externas parece ser um fator importante na limitação de uma expansão ainda maior desse tipo de trabalho. Com efeito, várias oficinas declararam que a qualidade do trabalho cai muito quando é realizado a domicílio (oficinas 1, 2, 3, 4 e 6), motivo pelo qual restringem seu uso a costureiras de confiança.

Outra questão que merece destaque é a descontinuidade do trabalho dessas mulheres, que se tornam extremamente dependentes das conjunturas que determinam seja a dinâmica de seus contratantes, seja a vida familiar. Entradas e saídas do mercado, entremeadas, muitas vezes, por longos períodos sem trabalho, parecem ser uma constante na vida dessas costureiras.

Finalmente, vale lembrar que o trabalho a domicílio pressupõe uma divisão do processo ainda maior do que o desenvolvido nas oficinas, tendo em vista que ele apresenta um caráter individual e que as trabalhadoras possuem, em geral, uma só máquina, na qual apenas determinados tipos de trabalho podem ser realizados.

\section{Estratégias sindicais na cadeia do vestuário}

Atualmente, além dos tradicionais problemas do setor de confecção, relacionados aos baixos salários e às más condições de trabalho, os sindicatos da categoria se defrontam com uma situação crítica: o notável aumento do trabalho desprotegido e a domicílio. Trabalhando sem carteira assinada, muitas vezes em suas próprias casas, os trabalhadores - trabalhadoras, em sua grande maioria - estão ausentes das estatísticas oficiais, assim como da categoria sindical da qual oficialmente não podem fazer parte.

A alta incidência do trabalho sem registro e a domicílio na categoria, bem como a tendência ao crescimento com o processo de terceirização, vêm levando os sindicatos a desenvolver estratégias diferenciadas para integrar essa mão-de-obra em seus quadros. Os tópicos a seguir buscam dar conta de algumas experiências interessantes nesse sentido. A discussão da experiência nacional estará centrada na análise da Confederação Nacional dos Trabalhadores na Indústria Têxtil, do Vestuário do Couro e de Calçados (CNTV), da Central Única dos Trabalhadores (CUT), do Sindicato das Costureiras de 
São Paulo e do Sindicato dos Trabalhadores nas Indústrias de Confecções e Bordados de Ibitinga e Região. Evidentemente, essas entidades não representam o conjunto do movimento sindical do setor; contudo, apresentam uma grande centralidade para a discussão, seja por sua representatividade e importância, como no caso das duas primeiras, seja por seu caráter inovador, como no caso do Sindicato de Ibitinga.

\section{Confederação Nacional dos Trabalhadores na Indústria Têxtil, do Vestuário do Couro e de Calçados}

A CNTV constitui um organismo nacional do setor, criado em 1994 pela CUT. Contando com 65 sindicatos filiados, ela representa 15 entidades sindicais do estado de São Paulo, das quais três são do setor do vestuário (ABC, Cotia e Sorocaba). No seu todo, a CNTV representa 121.984 trabalhadores do setor têxtil e do vestuário, que correspondem a $18,7 \%$ do total de trabalhadores do setor.

De acordo com seu presidente, a compreensão que a Confederação vem amadurecendo sobre o processo de reestruturação do setor é de que os efeitos negativos que ele vem tendo sobre a mão-de-obra se devem à estratégia de reestruturação adotada, centrada na competição por custos.

Para interferir neste quadro, a CNTV apresenta as seguintes propostas: elaboração de um projeto de política industrial para o setor, visando atender às exigências da competitividade por meio do redimensionamento das estratégias empresariais; normatização de um piso salarial nacional unificado, objetivando enfraquecer as estratégias baseadas na competição por custos; adoção da negociação articulada nos níveis nacional, regional e local, também visando enfraquecer as estratégias baseadas na competição por custos; elaboração de um projeto de campanha nacional em defesa do trabalho formal; e deflagração de uma campanha nacional contra o trabalho a domicílio, que inclui a publicação de um jornal nacional sobre o tema.

A Confederação elaborou também um código de conduta, já apresentado à ABIT, vinculando a obtenção de um selo de garantia internacional à eliminação do trabalho a domicílio e infantil. Esse código, entretanto, foi rejeitado pelo patronato, que o considerou uma ingerência indevida dos sindicatos em seus negócios.

Vale destacar que a CNTV vem participando também do Fórum da Competitividade da Cadeia Produtiva do Setor Têxtil e do Vestuário, criado pelo patronato e pelo governo federal em 2000, visando à elaboração de políticas voltadas ao aumento da penetração do produto brasileiro no mercado internacional. O fórum propôs o financiamento do BNDES (Banco Nacional de Desenvolvimento Econômico e Social) para o Senai (Serviço Nacional da 
Indústria) do setor, bem como para a criação de uma escola técnica de gestão empresarial. A postura da Confederação nessas reuniões tem sido a de insistir na vinculação do financiamento a políticas que garantam a qualidade do trabalho por parte das empresas. O projeto da CNTV é apresentar o Código de Conduta no fórum, a fim de reapresentar a discussão ao empresariado.

Segundo o presidente da Confederação, um dos principais problemas que o setor enfrenta no momento é a baixa capacidade de pressão sobre o patronato, em virtude do rápido processo de enxugamento dos empregos com registro 22 . Este quadro tem dificultado a discussão das estratégias empresariais de reestruturação, vistas pelo patronato como uma questão de domínio privado das empresas.

\section{Sindicato das Costureiras de São Paulo e Osasco}

A questão do trabalho a domicílio na categoria sempre foi uma preocupação do Sindicato das Costureiras de São Paulo. Ele começou a discutir o problema de maneira mais sistemática em 1997, quando a central sindical à qual está filiado (Força Sindical) iniciou uma reflexão sobre como integrar os trabalhadores desempregados e sem carteira assinada na vida sindical.

O principal passo nessa direção foi dado em 1998, quando o sindicato modificou seus estatutos para criar um novo tipo de sócio (sócio usuário), que permite a incorporação, em seus quadros, das costureiras sem vínculo empregatício, inclusive as que trabalham a domicílio. A partir de então, a política sindical é de incorporação total dessas trabalhadoras, buscando inclusive representá-las na negociação coletiva sempre que se consegue a comprovação do vínculo empregatício.

As tabelas 9 e 10, apresentadas abaixo, evidenciam o crescimento desses sócios, embora nem todos trabalhem a domicílio e seu número ainda seja pouco expressivo.

Vale destacar que, além de desfrutarem, em igualdade de condições, de todos os serviços do sindicato (Departamento Médico, Jurídico, Colônia de Férias), as trabalhadoras a domicílio vêm sendo incorporadas também aos cursos de qualificação e requalificação profissional oferecidos pelo sindicato (estilismo, costura de peças básicas, etc.).

Outra plataforma importante da política sindical é a luta pela regulamentação do trabalho a domicílio e a assinatura, pelo Brasil, do convênio 177 da Organização Internacional do Trabalho (OIT), sobre trabalho a domicílio. De acordo com a presidente do sindicato, a regulamentação seria fundamental para diminuir o tipo de competição entre as empresas, baseada na superexploração do trabalho. O patronato, entretanto, temeroso em 
relação à perda de competitividade, tem se mostrado extremamente resistente à regulamentação.

Tabela 9

\begin{tabular}{|c|c|c|c|c|c|c|}
\hline \multirow[t]{2}{*}{ Categorias } & \multicolumn{2}{|c|}{ Setembro de 2001} & \multicolumn{2}{|c|}{2000} & \multicolumn{2}{|c|}{1999} \\
\hline & $\begin{array}{l}\text { números } \\
\text { absolutos }\end{array}$ & $\%$ & $\begin{array}{l}\text { números } \\
\text { absolutos }\end{array}$ & $\%$ & $\begin{array}{l}\text { números } \\
\text { absolutos }\end{array}$ & $\%$ \\
\hline Sócio usuário & 357 & 5,6 & 250 & 3,8 & 150 & 1,9 \\
\hline Sócio normal & 4.900 & 77,1 & 5.119 & 77,9 & 6.610 & 84,1 \\
\hline Aposentados & 1.100 & 17,3 & 1.200 & 18,3 & 1.100 & 14,0 \\
\hline Total & 6.357 & 100,0 & 6.569 & 100,0 & 7.860 & 100,0 \\
\hline
\end{tabular}

Fonte: Sindicato das Costureiras de São Paulo e Osasco

Tabela 10

Número de sócios ativos* do Sindicato das Costureiras de São Paulo e Osasco - 1999-set 2001

\begin{tabular}{lcrr}
\hline Categorias & Setembro de 2001 & 2000 & 1999 \\
Sócio usuário & 29 & 20 & 20 \\
Sócio normal & 2.800 & 2.800 & 4.200 \\
Aposentados & 84 & 128 & 110 \\
Total & 5.013 & 2.948 & 4.330
\end{tabular}

Fonte: Sindicato das Costureiras de São Paulo e Osasco

* São aqueles que estão em dia com suas mensalidades; é muito difícil diferenciar, entre os sócios não ativos, aqueles que simplesmente estão atrasados no pagamento de suas mensalidades daqueles que já não têm mais interesse em participar da vida sindical.

\section{Sindicato dos Trabalhadores nas Indústrias de Confecções e Bordados de Ibitinga e Região}

Conhecida como a "capital nacional do bordado", Ibitinga é uma pequena cidade, com cerca de 50 mil habitantes, localizada no centro geográfico do estado de São Paulo. Com sua economia voltada basicamente para o setor da confecção e bordado, convive com uma altíssima incidência de trabalho a domicílio.

O Sindicato dos Trabalhadores nas Indústrias de Confecções e Bordados foi fundado em 1988 e segue uma política de representação dos trabalhadores a domicílio desde sua fundação. A estratégia sindical se baseou desde sempre na caracterização da relação de trabalho desses trabalhadores como uma relação de emprego que deve, portanto, ser regida pelo contrato de trabalho. Conforme explicita uma das diretoras do sindicato: 
"O trabalhador ibitinguense do bordado é o perfeito trabalhador a domicílio, pois se submete a uma direção, pelo empregador, na prestação de serviços, ou seja, a empresa intervém nas atividades, através da expectativa permanente, fiscalização, correções e imposições de preço, etc. Portanto, havendo a completa relação empregatícia, deve haver também o contrato de Trabalho e Previdência Social, resultando na garantia de todos os Direitos Trabalhistas" (O Comércio de Ibitinga, 08/05/1995, p. 5).

Essa posição do sindicato provém da interpretação que a entidade faz da legislação, que considera não haver distinção entre o trabalho efetuado no estabelecimento do empregador e o desenvolvido no domicílio do empregado:

“A legislação é bem clara: não há distinção entre o trabalho executado no estabelecimento do empregador e aquele realizado no domicílio do empregado. Com base no artigo 6o da Consolidação das Leis do Trabalho (CLT), será considerado empregado o trabalhador que prestar serviço em seu próprio domicílio, desde que esteja caracterizada a relação de emprego. A relação de emprego se caracteriza, portanto, sempre que alguém estiver prestando serviços a outrem sob dependência e mediante remuneração" (O Comércio de Ibitinga, 08/05/1995, p. 5).

Esse tipo de compreensão e estratégia levou o sindicato a desenvolver, desde o início de suas atividades, uma forte relação com os trabalhadores a domicílio, que sempre foram aceitos como sócios. A política praticada é de que basta ao trabalhador pagar a mensalidade para ter direito ao uso de todas as dependências e todos os serviços do sindicato, que, desde sua fundação, teve como uma de suas principais lutas o registro e o pagamento do piso salarial aos trabalhadores a domicílio. A estratégia sindical centrou-se, dessa forma, na figura do trabalhador a domicílio e na luta pelo registro em carteira, o que se expressava inclusive nas atividades do Departamento Jurídico: "Hoje o maior índice de trabalhadores que usufruem do Departamento Jurídico são trabalhadores que não têm registro na Carteira de Trabalho e Previdência Social e nunca receberam suas verbas trabalhistas", informava o jornal do sindicato (Nossa Luta), em julho de 1993.

A luta do sindicato redundou, em abril de 2001, na conquista da garantia do registro em carteira por todos os "empregados que executem serviços na empresa (salão), ou fora 'dele', com máquinas próprias ou de 'terceiros', garantindo a estes o salário e todos os benefícios adquiridos pela categoria" (Sindicato dos Trabalhadores na Indústria de Confecções e do Bordado de Ibitinga e Região, 2001).

De acordo com a presidente do sindicato, essa vitória, formalizada na convenção coletiva da categoria, foi fundamental. Graças a ela, o sindicato 
tem conseguido regularizar a situação de muitos trabalhadores a domicílio, os quais vêm diminuindo numericamente, bem como garantir o cumprimento dos direitos que esses trabalhadores conquistaram, especialmente o piso salarial.

\section{Conclusão}

A divisão do trabalho entre as empresas estudadas do setor de confecção em São Paulo configura um nítido processo de deterioração das condições de trabalho conforme vamos caminhando ao longo da cadeia. Os dados referentes à organização da produção e do trabalho indicam que as empresas líderes concentram a distribuição e o desenho; as confecções, o trabalho de processamento; e as oficinas de costura e o trabalho a domicílio, a montagem. O trabalho de concepção só existe nas empresas líderes e, no conjunto dos três segmentos de cadeia, predomina o trabalho simples, com máquinas automatizadas, desenvolvido em linha ou em postos individuais.

Já no que se refere ao perfil e às condições de trabalho, observamos o nítido predomínio de mulheres ao longo dos três segmentos, embora elas estejam menos concentradas nas empresas líderes (chegando a ser minoria na empresa líder 2) e nas de confecção (onde chegam a dividir em igualdade o trabalho com os homens, como na confecção 3). Já nas oficinas de costura, elas constituem a maioria, e no trabalho a domicílio, a quase totalidade dos trabalhadores.

Os dados relativos ao tipo de contrato evidenciam a prevalência absoluta do contrato escrito nas empresas líderes; nas confeccionistas, uma mescla entre contrato escrito e verbal nas oficinas de costura; e a ausência de contrato escrito entre as trabalhadoras a domicílio.

Finalmente, a deterioração das condições de trabalho, conforme se caminha na cadeia, se evidencia com salários mais baixos, jornadas que excedem as normas vigentes e altas taxas de risco que predominam nas oficinas de costura e no trabalho a domicílio. Trata-se, aliás, de um problema de extrema gravidade, tendo em vista os inadequados ambientes de trabalho, marcados, em geral, por má iluminação, acúmulo de poeira, pouco espaço e uso de cadeiras improvisadas.

Vale destacar, por fim, que, apesar dos esforços para incorporar estas mulheres em suas bases, os sindicatos vêm se mostrando pouco capazes de modificar a situação do setor. A preferência das mulheres por esse tipo de trabalho em razão de seus afazeres domésticos, sobretudo o cuidado com filhos pequenos, aliada à tendência à terceirização das empresas, dificulta a ação sindical. O sindicato pouco pode fazer para melhorar as condições em que o trabalho é prestado, em virtude de seu caráter doméstico, restando a 
luta pelo registro em carteira e pela garantia dos direitos trabalhistas. Esta é uma tarefa extremamente difícil, em face da tradição brasileira de não oficializar o trabalho a domicílio, embora o exemplo de Ibitinga mereça destaque como uma experiência promissora.

\section{Notas}

1 Professora livre-docente do DECISAE/Unicamp (Departamento de Ciências Sociais Aplicadas à Educação da Universidade Estadual de Campinas). <mpleite@uol.com.br>

2 Este texto é parte de um informe elaborado, em 2001, por Carlos Salas e por mim, para o projeto da OIT “Trabajo a domicilio y cadenas productivas en América Latina: Desafios para la acción sindical", atualizado e complementado com estudos mais recentes sobre o setor de confecções no Brasil. Agradeço a Silvana Maria de Souza, pelo auxílio no trabalho de campo, e a Carlos Salas, pela anuência em que eu publicasse separadamente a parte da pesquisa por mim realizada.

3 Empregamos o termo fordismo em seu sentido amplo, para designar não apenas a forma de organização do processo de trabalho no interior das empresas, mas também um determinado momento da acumulação capitalista, que inclui o tipo de estrutura industrial.

4 Nem sempre os encadeamentos produtivos seguem esse modelo, havendo setores em que o que se terceiriza são parcelas da produção de alto valor agregado. Observe-se, contudo, que a tendência a terceirizar a produção de partes de menor conteúdo tecnológico é a predominante no setor de produção de bens discretos.

5 A forma correta em português do termo é "trabalho em domicílio". Todavia, como a sociologia do trabalho brasileira, seguindo as recomendações da OIT (Organização Internacional do Trabalho), adotou a categoria "trabalho a domicílio" para designar o trabalho subcontratado exercido no domicílio do/a trabalhador/a — visando diferenciá-lo das demais formas de trabalho desenvolvidas na residência-, este será o termo aqui empregado.

6 Não se pode perder de vista, contudo, que outra forma bastante comum de surgimento das oficinas se dá com a demissão de costureiras das indústrias de confecção, muitas das quais são incentivadas pelos próprios empregadores a montar oficinas em suas casas (esse é o caso, por exemplo, da confecção 1 da nossa amostra, que trabalha com aproximadamente 40 oficinas, a maior parte delas montadas por ex-costureiras da empresa). É através desse processo que se vem dando também a difusão de cooperativas, incentivadas pelas empresas de confecção a partir da terceirização de parcelas do processo produtivo. Surgidas como formas de diminuir custos, tais cooperativas têm muito pouco a ver com o modelo de associativismo que subjaz ao movimento cooperativista. Ver, a respeito, Amorim (2003).

7 Vale registrar que a abertura inicial do mercado adotada no início dos anos 90 sofreu poucas alterações desde então, encontrando-se atualmente a alíquota padrão para as 
confecções, em geral, na casa dos $20 \%$. Não se pode esquecer, entretanto, que a variação na cotação do dólar, com tendência à desvalorização do real em relação à moeda norte-americana, tem funcionado nos últimos anos como um profundo desestímulo à importação.

8 Embora o panorama no setor de confecções tenha se estagnado, a indústria têxtil teve um comportamento diferente, logrando se modernizar. Suas empresas passaram por um processo importante de inovação tecnológica, adquirindo qualidade e ampliando significativamente a capacidade de exportação do setor nos últimos anos.

9 CAD - Computer Aided Design (Desenho Assistido por Computador).

10 De acordo com informações obtidas no sindicato, segundo o Centro de Saúde do Trabalho, o setor apresenta um dos maiores índices de doenças mentais.

11 Do total de 98 mil trabalhadores da base sindical de São Paulo e Osasco, cerca de 90\% eram mulheres, segundo dados de 1993 da subseção Dieese, do Sindicato das Costureiras e Trabalhadores da Indústria do Vestuário de São Paulo e Osasco.

12 Embora não haja dados oficiais sobre o trabalho a domicílio, a Pesquisa de Emprego e Desemprego da Fundação Seade e do Dieese registrava, em 1993, que apenas 52\% dos ocupados na indústria do vestuário na Grande São Paulo eram assalariados com carteira assinada e que, entre os $48 \%$ restantes, 13\% trabalhavam a domicílio (Fundação Seade, 1995). Tais dados indicavam uma nítida tendência ao aumento do trabalho a domicílio, tendo em vista que, em 1991, ele representava 9,5\% do total dos ocupados do setor na região.

13 Cumpre ressaltar que, além de todas as diferenças relacionadas às condições de trabalho entre esses três tipos de vínculo (direito aos benefícios associados à legislação trabalhista, como férias, décimo terceiro salário, assistência social, etc.), os dados sobre remuneração indicam uma situação nitidamente desvantajosa para os trabalhadores sem carteira e os por conta própria: a média salarial, em setembro de 1999, era de R\$363,00 para os trabalhadores com registro em carteira, de R\$ 246,00 para os sem registro e de apenas R\$ 130,00 para os por conta própria, categoria onde se concentram as trabalhadoras a domicílio.

14 De acordo com um ex-gerente de uma grande rede de distribuição, essa pressão é absolutamente implacável:

“É uma pressão enorme; os magazines não têm nenhum compromisso social e nem estratégia de longo prazo. Eles chegam até a suspender pedidos no meio da produção, por exemplo, porque não está fazendo o frio que se esperava. Nesses casos, é a produção que tem que arcar com o prejuízo. Como há muita empresa de confecção, a dependência em relação aos distribuidores se torna desproporcional. Pra você ter uma idéia, a empresa X não reajusta o valor pago para as peças de roupa que encomenda há mais de cinco anos. A relação dos magazines com os produtores não é uma relação de parceria; são puros acordos comerciais. Muito raramente - e apenas para os fornecedores top de linha - existe algum tipo de ajuda para a participação em feiras ou visitas ao exterior". (ex-gerente da distribuidora de confecções)

15 Estamos utilizando os termos 'oficina' e 'facção' como Spindel (1983), que os emprega como sinônimos. Outros autores, entretanto, como Nunes Filho, consideram que as facções constituiriam um nível acima na cadeia de produção, enquanto as oficinas seriam unidades produtivas menores e mais precárias que as facções, emergidas do mercado de trabalho informal (Nunes Filho, 2002, p. 126). Minha decisão de utilizar os dois termos como 
sinônimos buscou respeitar a maneira como os próprios agentes sociais entrevistados se referiam aos estabelecimentos.

16 Embora não se possa esquecer que uma parte importante da concepção - o design — é normalmente definido nas distribuidoras.

17 É importante lembrar que essa empresa foi, até 1990, uma grande confecção que vendia para grandes magazines (Sears, Mappin, C\&A, etc.). Em 1990, com o Plano Collor, frente à enorme diminuição de pedidos por parte dos magazines, a empresa começou a abrir lojas próprias; a experiência deu certo, e hoje, além da confecção, a empresa administra uma marca - que se tornou uma grife - através de lojas próprias, situadas especialmente em shopping centers, e de uma cadeia de cerca de 50 lojistas que vendem a marca. Vale destacar que esse processo vem acontecendo, em geral, com as confecções que conseguem firmar uma marca, as quais começam a concentrar cada vez mais sua atividade na distribuição. O aprofundamento desse processo pode ser facilmente constatado pelas palavras do gerente: "Hoje estamos implementando uma nova fase da terceirização porque diminuímos a produção de modelos próprios. A empresa passou a comprar muita coisa pronta, em que a gente só põe a etiqueta. Às vezes, nem o design é interno; o departamento de desenvolvimento aprova o produto, e a gente manda a etiqueta. Só compramos e distribuímos para as lojas". (gerente da confecção 2). Observe-se que essa política de competitividade, tendo como foco a atuação em nichos específicos e dinâmicos, vem sendo importante para o setor. Conforme explicita Comin, alguns fabricantes de roupas infantis e de moda jovem praticamente se reinventaram nestes últimos anos, eliminando boa parte de seus empregos diretos, investindo em marcas e lojas próprias. Segundo o autor, embora ainda seja cedo para avaliar a importância desse tipo de estratégia, somente nesse nicho infanto-juvenil (no qual se insere a confecção em questão) já atuam mais de 1.300 empresas (Comin, 2000, p. 15).

18 CAM — Computer Aided Manufacturing (Manufatura Assistida por Computador).

$19 \mathrm{Na}$ oficina 1 , que funcionava na casa do sogro do proprietário, as máquinas se distribuíam por três cômodos, havendo, inclusive, duas instaladas na varanda.

20 A questão dos prazos assume enorme centralidade na indústria da confecção, tendo em vista que as vendas são extremamente dependentes das mudanças de estação e que as constantes variações da moda incidem sobre a capacidade das distintas marcas de colocar seus produtos no mercado em momentos exatamente determinados. Essa realidade vem sendo ainda mais pressionada por duas tendências que atuam simultaneamente sobre o setor: por um lado, a tendência de as empresas trabalharem com uma enorme variação de modelos traz grandes dificuldades de programação; por outro, o just-in-time e a diminuição dos estoques nas lojas exigem um constante trabalho de reposição, para o qual a entrega das peças dentro dos prazos assume grande importância.

${ }^{21}$ A fala do gerente remete a uma prática comum no setor, relativa à adoção de códigos de conduta pelas empresas, os quais constituem normas mínimas de qualidade do trabalho a serem seguidas, controladas através da adoção de selos de garantia.

22 Cumpre lembrar que o setor quase não vem sendo atingido pelo desemprego, mas sim pela queda do emprego registrado. 


\section{Referências bibliográficas}

ABRAMO, Lais. 1997. Imágenes de género y políticas de recursos humanos en un contexto de modernización productiva. Santiago, Chile: Ilpes (Instituto Latinoamericano de Planificación Económica y Social). . 1998. Um olhar de gênero: visibilizando a precarização ao longo das cadeias produtivas. In: Gênero e trabalho na sociologia Latino-Americana (Abramo, L. e Abreu, A. R. de P., orgs.), pp. 39-61, São Paulo/Rio de Janeiro: ALAST (Asociación Latinoamericana de Sociologia del Trabajo). (Série II Congresso LatinoAmericano de Sociologia do Trabalho).

ABREU, Alice. 1986. O avesso da moda: trabalho a domicílio na indústria de confecção. São Paulo: Hucitec.

- e SORJ, Bila 1994. Subcontratação e relações de gênero na indústria de confecção. In: O trabalhador carioca: estudos sobre trabalhadores urbanos no Rio de Janeiro (Abreu, A. e Pessanha, E., orgs.), pp. 139-153, Rio de Janeiro: JC Editora.

AMORIM, Elaine 1999. O trabalho feminino no novo paradigma produtivo: uma análise das trabalhadoras das indústrias têxteis e do vestuário de Campinas e Americana. Relatório Final apresentado à Fundação de Amparo à Pesquisa no Estado de São Paulo, Campinas.

. 2003. No limite da precarização? Terceirização e trabalho feminino na indústria de confecção. Dissertação de Mestrado, Campinas: IFCH (Instituto de Filosofia e Ciências Humanas, Unicamp. . e ARAÚJO, Ângela 2002. Redes de subcontratação e trabalho a domicílio na indústria de confecção: um estudo na região de Campinas. Cadernos Pagu 1718:267-310.

ARAÚJO, Ângela e AMORIM, Elaine 2000. Redes de subcontratação e trabalho a domicílio na indústria de confecção: um estudo na região de Campinas, trabalho apresentado no XXIV Encontro Anual da ANPOCS (Associação Nacional de Pós-Graduação em Ciências Sociais), Caxambu.
BENERÍA, Lourdes e ROLDÁN, Marta 1987. The crossroads of class and gender. industrial homework, subcontracting and household dynamics in Mexico city. Chicago: University of Chicago Press.

CASTILLO, Juan e SANTOS, Maximiano 1993. La cualificación del trabajo y los distritos industriales. Economía y Sociología del Trabajo, 21-22:51-61.

COMIN, Alexandre 2000. Reestruturação e concorrência na indústria brasileira de vestuário e calçado. Relatório Final do Projeto “Reestruturação produtiva, política industrial e contratação coletiva nos anos 90: as propostas dos trabalhadores". São Paulo: Finep.

CORIAT, Benjamin 1992. Pensar al reves. Madri: Siglo XXI.

COUTINHO, Luciano. e FERRAZ João. 1994. Estudo da competitividade da indústria brasileira. Campinas: Papirus.

CUT/DESEP 1999. Caderno Sintese do Setor Têxtil e Vestuário, elaborado a partir do Relatório Final do Projeto de Pesquisa e Formação Sindical "Reestruturação produtiva, politica industrial e contratação coletiva nos anos 90: as propostas dos trabalhadores", 1a fase, São Paulo: Finep. - 2001. Caderno Síntese do Setor Têxtil e Vestuário, elaborado a partir do Relatório Final do Projeto de Pesquisa e Formação Sindical "Reestruturação produtiva, politica industrial e contratação coletiva nos anos 90: as propostas dos trabalhadores", 2 a fase, São Paulo: Finep.

FOLHA DE SÃO PAULO. 2003. Ilegal, latino-americano vira "sem-saúde". Folha de São Paulo, 16 mar., p. C7.

FUNDAÇÃo SEADE. 1995. A indústria de confecções em São Paulo. Pesquisa de Emprego e Desemprego, Estudo Especial, Suplemento do Boletim da PED 120, São Paulo.

KAMADA, Toshiko 1994. Japanese management and the loaning of labour: reestructuring in the Japanese iron and steel industry. In: Global Japanization? (Elger, T. e Smith, C., eds.), pp. 91-111, Londres: Routledge. 
KERGOAT, Daniele 1987. Em defesa de uma sociologia das relações sociais: da análise crítica das categorias dominantes à elaboração de uma nova conceituação. In: O sexo do trabalho, obra coletiva, pp 79-93, São Paulo: Paz e Terra.

LAVINAS, Lena et al. 1998. Trabalho a domicílio: novas formas de contratualidade. Projeto Inter-regional OIT/Danida (Organização Internacional do Trabalho/ Organização Dinamarquesa para o Desenvolvimento) "Trabalho a domicílio na economia global". Relatório de Pesquisa preparado para a Consulta técnica preliminar sobre trabalho a domicílio na América Latina. Santiago, Chile: OIT.

LIMA, Jacob 1998. Cooperativas de produção industrial: autonomia e subordinação do trabalho. In: A ocupação na América Latina: tempos mais duros (Castro, N. e Dedecca, C., orgs.), pp. 211-229, São Paulo/Rio de Janeiro, ALAST. . 1999. Novas formas, velhos conteúdos: diversidade produtiva e emprego precário na indústria do vestuário. Revista Politica e Trabalho 15:121-139.

. 2002. As artimanhas da flexibilização: o trabalho terceirizado em cooperativas de produção. São Paulo: Terceira Margem.

MINISTÉRIO DO TRABALHO E EMPREGO. 2001. Relação Anual de Informações Sociais (Rais), Anuário Estatístico.

MOREIRA, Maria Vilma 1997. A inserção da mão-de-obra feminina na indústria de confecção no Ceará: o caso das cooperativas de confecções do Maciço de Baturité. Cadernos $C R H$ no. 26-27, p. 351373, Salvador: UFBA (Universidade Federal da Bahia).

NOSSA LUTA.1993. Exija seus direitos: Procure o departamento jurídico do Sindicato. Nossa Luta, jul., p. 2.

NUNES FILHO, Geraldo 2002. Vida, trabalho e saúde: costureiras a domicílio. Tese de Doutorado, São Paulo: Faculdade de Saúde Pública da Universidade de São Paulo.

O COMÉRCIO. 1995. Trabalho a domicílio. O Comércio, 8 maio, p. 5.
O ESTADO DE SÃO PAULO. 2001. Mão-deobra imigrante ocupa vazio de mercado, O Estado de São Paulo, 18 mar., p. A20.

PIORE, Michael e SABEL, Charles 1984. The second industrial divide. Nova York: Basic Books.

SINDICATO DOS TRABALHADORES NA INDÚSTRIA DE CONFECÇÕES E DO BORDADO DE IBITINGA E REGIÃO. 2001. Convenção Coletiva.

SPINDEL, Cheiwa 1983. O "uso" de trabalho na indústria do vestuário. In: $M u$ lher, mulheres (Barroso, C., org.), pp. 89113, São Paulo, Cortez Editora.

TOMEI, Manuela. 1999. El trabajo a domicilio en paises selecionados de América Latina: una visión comparativa. Proyecto Interregional OIT/Danida "Trabajo a domicilio en la economía global". Santiago, Chile: OIT.

WOMACK, James et al. 1992. A máquina que mudou o mundo. Rio de Janeiro: Editora Campus. 